\title{
Imaging Biomarkers for Monitoring the Inflammatory Redox Landscape in the Brain
}

\author{
Eduardo Felipe Alves Fernandes ${ }^{1}$ and Dennis Özcelik ${ }^{1,2, * \mathbb{D}}$ \\ 1 Department of Drug Design and Pharmacology, University of Copenhagen, Universitetsparken 2, \\ 2100 Copenhagen, Denmark; eduardo.fernandes@sund.ku.dk \\ 2 Chemistry | Biology | Pharmacy Information Center, ETH Zürich, Vladimir-Prelog-Weg 10, \\ 8093 Zürich, Switzerland \\ * Correspondence: dennis.ozcelik@chem.ethz.ch
}

Citation: Fernandes, E.F.A.; Özcelik,

D. Imaging Biomarkers for

Monitoring the Inflammatory Redox Landscape in the Brain. Antioxidants 2021, 10, 528. https://doi.org/

$10.3390 /$ antiox 10040528

Academic Editor: Peter L. Oliver

Received: 18 February 2021

Accepted: 25 March 2021

Published: 28 March 2021

Publisher's Note: MDPI stays neutral with regard to jurisdictional claims in published maps and institutional affiliations.

Copyright: (c) 2021 by the authors. Licensee MDPI, Basel, Switzerland. This article is an open access article distributed under the terms and conditions of the Creative Commons Attribution (CC BY) license (https:// creativecommons.org/licenses/by/ $4.0 /)$.

\begin{abstract}
Inflammation is one key process in driving cellular redox homeostasis toward oxidative stress, which perpetuates inflammation. In the brain, this interplay results in a vicious cycle of cell death, the loss of neurons, and leakage of the blood-brain barrier. Hence, the neuroinflammatory response fuels the development of acute and chronic inflammatory diseases. Interrogation of the interplay between inflammation, oxidative stress, and cell death in neurological tissue in vivo is very challenging. The complexity of the underlying biological process and the fragility of the brain limit our understanding of the cause and the adequate diagnostics of neuroinflammatory diseases. In recent years, advancements in the development of molecular imaging agents addressed this limitation and enabled imaging of biomarkers of neuroinflammation in the brain. Notable redox biomarkers for imaging with positron emission tomography (PET) tracers are the $18 \mathrm{kDa}$ translocator protein (TSPO) and monoamine oxygenase $\mathrm{B}(\mathrm{MAO}-\mathrm{B})$. These findings and achievements offer the opportunity for novel diagnostic applications and therapeutic strategies. This review summarizes experimental as well as established pharmaceutical and biotechnological tools for imaging the inflammatory redox landscape in the brain, and provides a glimpse into future applications.
\end{abstract}

Keywords: oxidative stress response; reactive oxygen species; imaging biomarker; redox sensor; microglia; positron emission tomography; TSPO; MAO-B

\section{Introduction}

Neuroinflammation is a complex and poorly understood phenomenon with high clinical relevance. A large number of disorders of the central nervous system (CNS) show a substantial neuroinflammatory component. Notable examples are neuropsychiatric diseases, such as schizophrenia and bipolar disorder [1-3]. Inflammatory processes also play an important role in many autoimmune disorders of the CNS, of which multiple sclerosis (MS) is the most common one [4]. Despite the rapidly increasing incidence, the cause of MS is still under debate [5]. It is clear, however, that the immune system eliminates the myelin layers of nerve fibers [6]. These continuous attacks result in local inflammation sites within the myelin sheath and, eventually, recognizable lesions in magnetic resonance imaging (MRI) scans. These inflammation events disrupt the neuronal networks and, hence, are responsible for a highly diverse array of symptoms. Neurodegenerative diseases are another group of CNS disorders that display chronic inflammation of the brain. A notable representative of this group is Alzheimer's disease (AD), which is also the leading cause of dementia [7].

A growing body of research provides evidence for chronic neuroinflammation as a cause for AD development, which is comprehensively summarized elsewhere [8,9]. For example, a number of studies found an elevated level of inflammation markers, e.g., the cytokines interleukin-1 beta (IL-1 $\beta$ ), IL-6, and tumor necrosis factor $\alpha$ (TNF- $\alpha$ ), in mouse models and AD patients [8,10-12]. Another study demonstrated that the innate immunity 
protein interferon-induced transmembrane protein 3 (IFITM3) is associated with A $\beta$ production [13]. This study also linked the age-dependent increase of inflammatory markers, such as type I interferons [14], to concomitantly increased IFITM3 levels in the elderly, ultimately matching the clinical manifestation of $\mathrm{AD}$ as a late-developing neurological disease. Other studies showed that anti-inflammatory molecules enhance [15], or that proinflammatory molecules decrease $A \beta$ clearance by the triggering receptor expressed on myeloid cells 2 (TREM-2) [16-18]. We refer the interested reader to the up-to-date review from Shi and Holtzman on the role of TREM-2, APOE, and disease-associated microglia in inflammation in AD [19].

In contrast to $\mathrm{AD}$ and other neurodegenerative diseases, which are associated with chronic inflammation, ischemic stroke is a representative example of a pathology that is associated with acute inflammation [20]. In ischemic stroke, occlusion of, usually, the middle cerebral artery reduces or blocks the blood flow in the human brain, which causes hypoxia in cortical brain areas [21]. Low oxygen levels trigger a vast and complex biochemical cascade encompassing inflammation, which finally causes neuronal cell death and impaired brain function [22].

A major factor for neuronal cell death in inflammation is oxidative stress. Oxidative stress is characterized by a relative increase of reactive oxygen species (ROS), which leads to an imbalance of the tightly regulated redox homeostasis of the cell $[23,24]$. This imbalance jeopardizes cellular function and survival, because ROS can react with a wide variety of biological biomolecules, causing, for instance, DNA damage [25] and protein modification [26], and eventually leading to apoptosis [27]. Moreover, ROS and oxidative stress can activate inflammatory signaling pathways and, hence, induce the production of numerous proinflammatory cytokines that drive inflammation [28]. Proinflammatory cytokines activate immune cells, amplifying both inflammation and ROS generation. Hence, the neuroinflammatory response fuels oxidative stress, which perpetuates inflammation.

Initial causes of the inflammatory responses and oxidative stress are perturbation in the cellular metabolism due to genetic anomalies or environmental factors. Typical examples of such environmental factors comprise lifestyle choices, for instance, physical exercise, diet, smoking, and alcohol consumption [29,30]. Consequently, these factors correlate with the development of stroke [31-33], neurodegenerative disorders [34,35], and other inflammatory brain diseases [36,37]. Other known external factors are pathogens, e.g., viruses and bacteria [38], and physical injuries, e.g., traumatic brain injury [39]. Environmental pollutants are another important factor that is connected to inflammation [40]. Many pollutants, e.g., metals [41], pesticides [42-44], and microplastic [45,46], are suspected to impair well-being. Furthermore, a large amount of research has established over the years that air pollution is associated with inflammatory processes in the body, including the brain [47-49]. For instance, a very recent study showed a correlation between air quality and the development of neurodegeneration [50].

In order to diagnose and treat many CNS diseases, it is crucial to understand, assess, and monitor the neuroinflammatory response in the brain. This, however, is a major challenge because of the complexity of the underlying biochemical processes of inflammation, particularly in the brain. Consequently, a lack of tools prohibits interrogating neuroinflammatory components and pathways for diagnostic and clinical purposes. The advent of chemical and synthetic biology might provide the research community and clinical professionals with novel means to trace the development of inflammatory processes in the human brain.

In this review, we summarize the inflammatory response and its interaction with the redox landscape, in particular, in the CNS. We further describe available and experimental tools and methods for monitoring key players in the redox landscape of inflammation in the brain. Finally, we present examples of promising applications in the clinical setting. 


\section{Redox Biology of Inflammation}

\subsection{Interplay of Oxidative Stress and Inflammation}

Inflammation is a complex physiological process, which is associated with five characteristic symptoms: pain, redness, swelling, heat, and loss of function. Typically, inflammatory processes can be classified as acute or chronic inflammation (Figure 1). Acute inflammation is a direct response of the body and fades within a limited amount of time, usually within a few days. Subacute inflammation persists up to six weeks, whereas longer periods are deemed chronic. Chronic inflammation can last for years, and is associated with numerous pathologies (Figure 1).

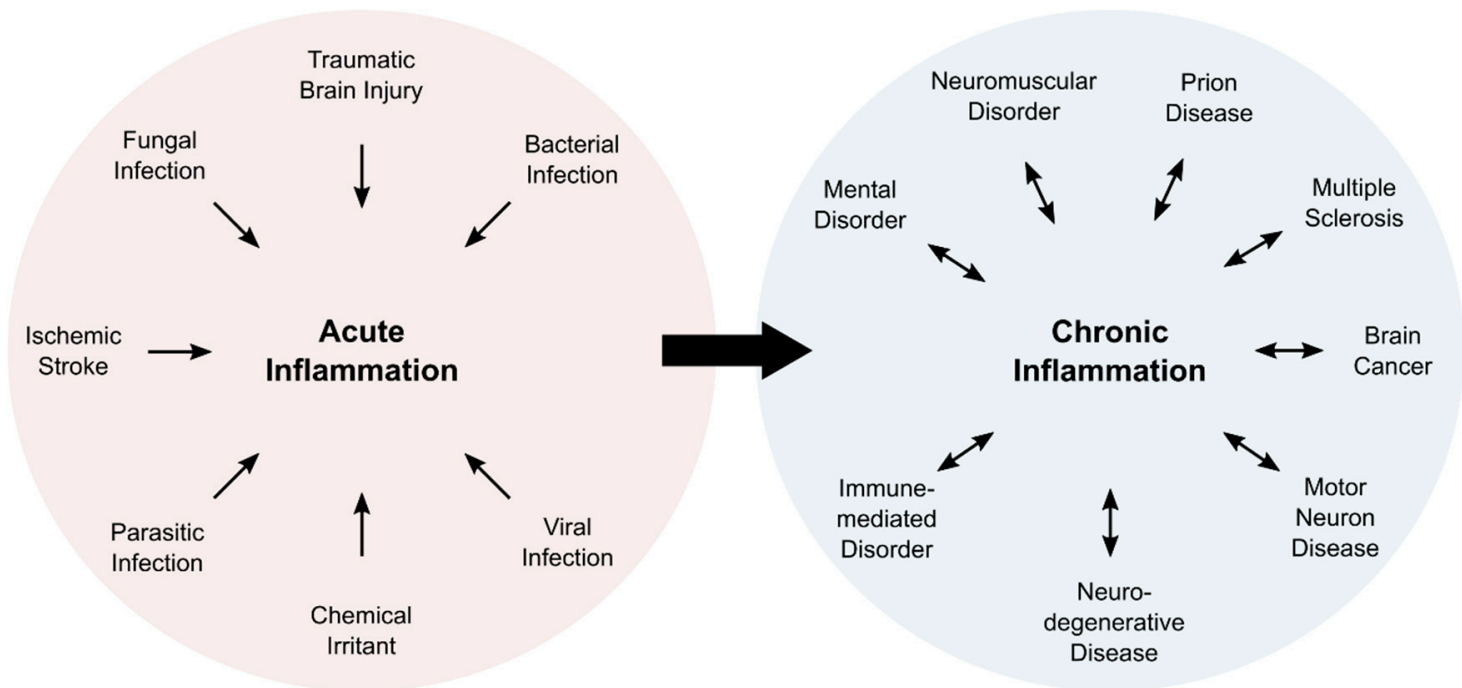

Figure 1. Overview of cause and consequence of acute and chronic inflammation. Acute inflammation is induced in response to external factors. Persisting inflammatory responses become chronic events that are associated with numerous pathologies.

Upon exposure to a pathogen, an irritant, or cell damage, leukocytes enter the affected tissue in order to eliminate the intruding pathogen, limit propagation of damage, and stimulate tissue repair processes [51]. Cells in the surrounding area secrete cytokines, in particular, IL-1 $\beta$, IL-6, and TNF- $\alpha$, to further attract and to activate cells of the immune system from the bloodstream or the local tissue [52,53]. An important effect of the inflammatory response is the alteration of redox environment [54,55].

The redox environment is tightly regulated to enable controlled biochemical reactions and molecular interactions in the cell and the organism [23,56-58]. In this environment, oxygen very often takes the prominent role as the terminal electron acceptor. The electron transfer to oxygen results in by-products, in particular, ROS that include superoxide anion $\left(\mathrm{O}_{2}{ }^{\bullet-}\right)$, hydroxyl radical $\left(\mathrm{OH}^{\bullet}\right)$, and hydrogen peroxide $\left(\mathrm{H}_{2} \mathrm{O}_{2}\right)$. Naturally, cells produce a basal level of ROS in the mitochondria, the endoplasmic reticulum (ER), and the peroxisomes [59]. The major sources of intracellular ROS in these organelles are nicotinamide adenine dinucleotide phosphate (NADPH) oxidases (NOXs), mitochondrial electron transport chains, as well as ER oxidoreductases [60-62]. Under normal conditions, the cell is able to contain ROS, but overproduction leads to oxidative stress that impairs other physiological pathways [24,63].

A large number of studies established the interlocked nature of inflammation and oxidative stress. For instance, ROS regulate $\mathrm{T}$ cell responses, which indicates that oxidative stress can trigger an erroneous immune response, which fuels ongoing immune reactions $[64,65]$. In addition, ROS react with redox-sensitive proteins in the cell, and thus modulate crucial inflammatory signaling pathways, such as the MAPK/ERK pathway [66-68] or the NF-kB pathway [69-71]. Another important example of the interplay of oxidative stress and inflammation is the induction of the "respiratory burst" in phagocytic cells of the immune system, e.g., neutrophils, monocytes, and macrophages. This rapid 
production of ROS and other radicals, such as nitric oxide $\left(\mathrm{NO}^{\bullet}\right)$, serves to eliminate the pathogen and to stimulate the cytokine response by the leukocytes [72,73]. The central component of the increased ROS production is the NADPH oxidase 2, which is also termed NOX2 in humans $[74,75]$. NOX2 is present in multiple cell types and is responsible for the production of constitutive but low levels of ROS. During the respiratory burst, however, NOX2 activity increases substantially in phagocytes, which is associated with an up to 100-fold increase in oxygen consumption, and causes the physiologically induced oxidative stress event $[76,77]$.

A large body of research provides compelling evidence for the important contribution of both oxidative stress and inflammation to the development of pathogen-independent inflammatory diseases, such as cancer, diabetes, or neurodegenerative diseases [78,79]. If left unchecked, inflammation and oxidative stress mutually perpetuate each other, driving the affected tissue in a vicious cycle to massive damage. Hence, the interplay of the redox landscape and inflammation draws considerable attention in current research efforts.

\subsection{Induction of the Inflammatory Response}

Activation of inflammatory signaling pathways is facilitated by various signals that also include oxidative stress. Upon recognition of an external stimulus, the innate immune system induces an inflammatory response. This recognition is mediated by pattern recognition receptors (PRRs) that sense pathogen-associated molecular patterns (PAMPs) and danger-associated molecular patterns (DAMPs). Besides membrane-bound PPRs, e.g., the Toll-like receptors (TLRs), that sense extracellular or endosomal signals, intracellular PPRs, including the nucleotide-binding domain and leucine-rich repeat-containing receptors (NLRs), and absent in melanoma 2 (AIM2)-like receptors (ALRs), recognize intracellular signals. A subgroup of cytosolic PPRs contributes to the assembly of the inflammasome [80]. The inflammasome is an intracellular multiprotein complex that activates and secretes the proinflammatory cytokines IL-1b and IL-18 [81]. Inflammasome activation depends on a number of factors, and ROS are known modulators of inflammasome activity [82].

It has been shown that $\mathrm{H}_{2} \mathrm{O}_{2}$ produced by the mitochondrial enzyme monoamine oxidase $\mathrm{B}(\mathrm{MAO}-\mathrm{B})$ is crucially involved in the activation of the inflammasome [83]. This remarkable study also suggested that $\mathrm{MAO}-\mathrm{B}$ could be exploited as a target for therapeutic modulation of inflammatory signaling. Besides direct modulation of inflammasomal activity, redox signaling can also indirectly regulate the inflammasome. For instance, an earlier study showed that liposomes could activate the NLRP3 inflammasome, which involves ROS and ROS-dependent calcium influx [84]. A more recent study showed that the $18 \mathrm{kDa}$ translocator protein (TSPO), located in the outer mitochondrial membrane, is a key regulator of calcium homeostasis [85]. Since calcium signaling and mitochondrial destabilization induce the NLRP3 inflammasome [86], it seems to be plausible that TSPO contributes to the regulation of inflammasomal activity.

The activity of the inflammasome induces an inflammatory cascade that results in pyroptosis, a certain type of programmed cell death [87]. Pyroptosis requires activation of caspases, e.g., caspase-1, and stimulates the production of proinflammatory cytokines and gasdermins [88]. Gasdermins are pore-forming proteins that rupture the cell membrane, enabling the release of cytokines and DAMPs that perpetuate the inflammatory response by recruiting immune cells to the tissue $[89,90]$. Hence, inflammasomes play a key role in the inflammatory response, and were initially studied in cells of the innate immune system. PPRs are expressed in macrophages, NK cells, neutrophils, mast cells, and other cells of the innate immune system. Nevertheless, a large body of research also described inflammasomes in epithelial cells [80].

Given the central role in the inflammatory response, the inflammasome has drawn considerable attention as a drug target to tackle inflammatory diseases [91]. Inflammasome activation and cytokines production have been targeted by antagonists of the IL-1 receptor (e.g., anakinra), IL-1b neutralizing antibodies (e.g., canakinumab), and soluble decoy receptors for IL-1b and IL-1a (e.g., rilonacept) [92]. In addition, several compounds have been 
described for targeting subunits of the inflammasomes, such as NLRP3, caspase-1, and gasdermin D [93,94]. Despite all efforts, our current understanding of inflammasome signaling and the inflammatory response is still very limited, particularly in CNS inflammation.

\subsection{The Neuroinflammatory Response}

The brain, but also the entire central nervous system (CNS), is an immunologically privileged site, and possesses a distinct immune system that protects neuronal cells against pathogens $[95,96]$. The neuroimmune system comprises the highly diverse group of nonneuronal glial cells, which can roughly be divided into macroglia (e.g., astrocytes, enteric glial cells, ependymal cells, oligodendrocytes, radial glia, satellite cells, and Schwann cells) and microglia [97]. The latter ones are the major components of the neuroimmune system, and act as resident macrophages in the CNS [98]. They also express PPRs [99]; however, inflammatory signaling was also described for neurons [100], astrocytes [101], perivascular CNS macrophages [102], oligodendrocytes [103], and endothelial cells [104].

Upon activation, microglia release proinflammatory cytokines, such as IL-1 $\beta$, IL-6, and TNF- $\alpha[52,105,106]$. Like the immune cells of the bloodstream, microglia are also capable of undergoing respiratory burst phases that are mediated by an increase in NOX2 activity. ROS production is a crucial tool that microglia utilize in response to pathogens, protein aggregates, or cell debris [107,108]. For more detailed information on ROS generation in microglia, the interested reader is referred to a comprehensive review by Simpson and Oliver [109].

The inflammatory response in the brain and elsewhere is tightly regulated. Limited inflammation can fail to clear an infection, whereas overreaction can induce massive tissue damage $[51,110,111]$. Similarly, ongoing and chronic inflammation lead to severe side effects and physiological complications. A notable consequence of neuroinflammation affects the blood-brain barrier (BBB) [112]. The BBB consists of a layer of endothelial cells that create a highly selective semipermeable boundary, which separates the CNS from the circulating blood, and protects it from pathogens [113]. The BBB also prevents the passage of antibodies and immune cells. Moreover, the BBB limits the uptake of certain drugs, including antibiotics, to the CNS, making the BBB a considerable obstacle in the treatment of CNS diseases. Neuroinflammation can lead to increased permeability of the BBB, enabling infiltration of leukocytes, which can then participate in perpetuating the inflammatory response [51,111]. An overview of the neuroinflammatory response is presented in Figure 2.

Proinflammatory cytokines directly and indirectly increase neuronal cell damage. For instance, IL-1 $\beta$ causes neurotoxic effects by a variety of pathways [114], including the induction of oxidative stress $[115,116]$. IL-6 has an important function in neuronal tissue homeostasis, but overproduction leads to neurodegeneration $[117,118]$. Furthermore, IL-6 also mediates upregulation of VCAM-1 that leads to permeability of the BBB, allowing infiltration of leukocytes [119]. TNF- $\alpha$ recruits leukocytes from the periphery into the brain, and directly affects endothelial cells, eventually leading to increased BBB permeability [120]. In addition, TNF- $\alpha$ potentiates glutamate-induced cell death in hippocampal slides: it inhibits glutamate transporters, increases the expression of $\alpha$-amino-3-hydroxy-5-methyl4-isoxazolepropionic acid (AMPA) receptors, and, ultimately, elevates the levels of the oxidative effector nitric oxide synthase, which yields oxidative stress [121].

As illustrated, the redox landscape plays a crucial role in the development and progression of neurological diseases. Hence, experimental and translational methods are necessary to interrogate the progression of inflammatory and oxidative biomarkers in neurological diseases. 


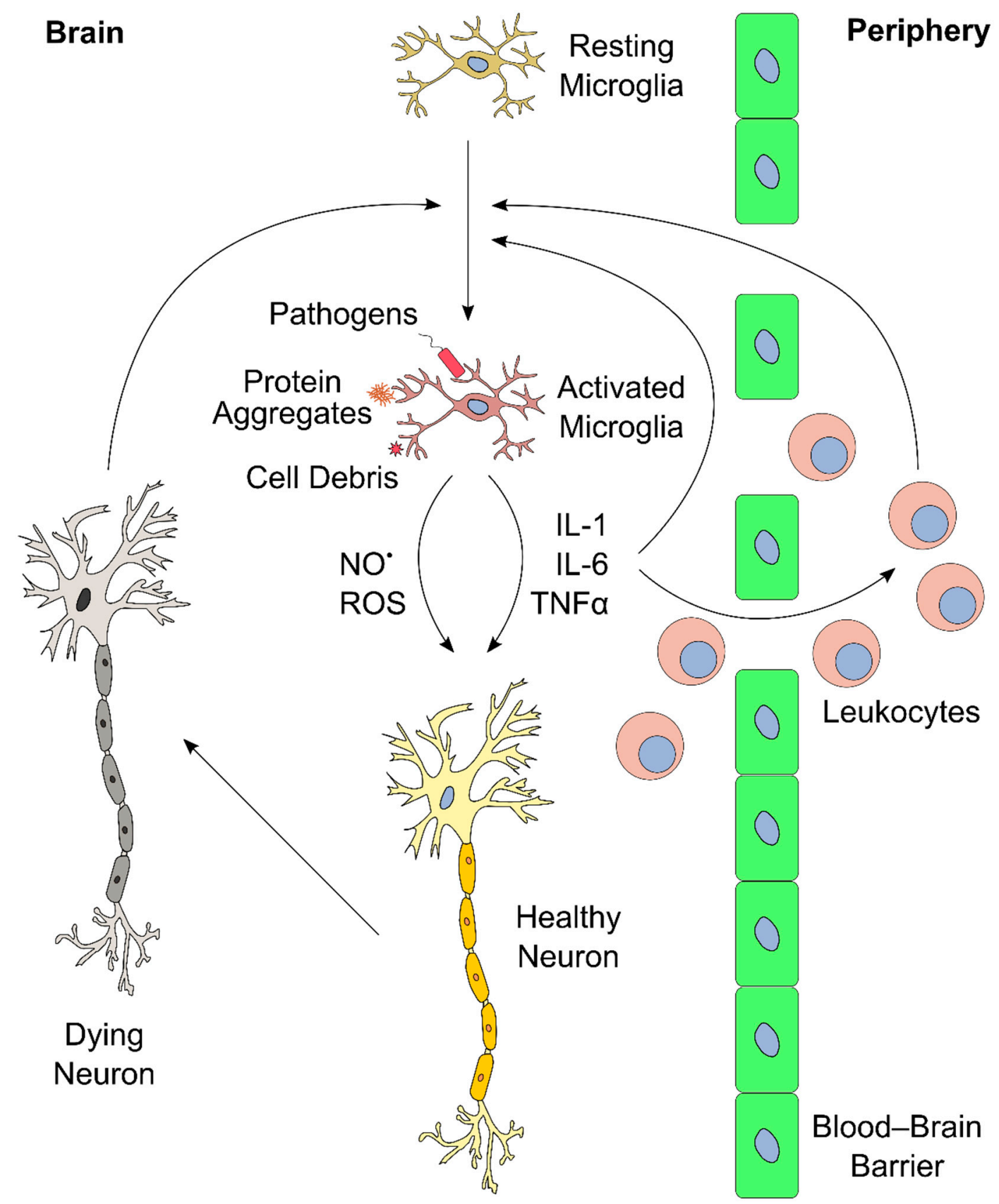

Figure 2. Schematic overview of brain inflammation. Resting microglia in the brain become activated upon exposure to external stimuli (e.g., pathogens, protein aggregates, cell debris). This induces proliferation and release of cytokines (e.g., interleukin-1 (IL-1), IL-6, and tumor necrosis factor $\alpha(\mathrm{TNF}-\alpha)$ ), reactive oxygen species (ROS), and reactive nitrogen species (RNS, such as $\mathrm{NO}^{\bullet}$ ). These inflammatory mediators further stimulate other microglia in the brain. In addition, cytokines and ROS affect neurons, and propagate cell death upon extended exposure, which, in turn, could further stimulate microglia in the central nervous system (CNS). Furthermore, the inflammatory mediators act in the blood-brain barrier, and recruit leukocytes from the periphery into the brain. Leukocytes can perpetuate the inflammatory process even further, for instance, via secretion of additional cytokines. These positive feedback mechanisms can lead to a vicious cycle of inflammation and neuronal death.

\section{Tools and Methods to Monitor the Redox Landscape of Neuroinflammation}

\subsection{Monitoring the Redox Landscape in the Laboratory}

Since inflammation and oxidative stress are tightly connected, the monitoring of ROS can provide valuable information about the biological processes during inflammation. One major challenge in this area of research is the limitation of available tools to monitor and 
to detect oxidative stress and inflammation. Over the years, scientists have developed a plethora of tools to study the production of ROS in cellular models. In general, there are two types of sensors to monitor the redox state in living cellular systems: genetically encoded redox proteins and small-molecule probes. These tools have been described numerous times, and we recommend a selection of comprehensive overviews that provide a detailed summary of genetically encoded redox proteins [122] and small-molecule redox sensors, including recent positron emission tomography (PET) tracers [123,124].

A significant body of research is devoted to the development and improvement of genetically encoded redox proteins. Recent advances led to novel fluorophores, for instance, a fluorescent protein that displays a redox-dependent change from green to blue [125]. Further, many studies reported the development of sensors for specific biomolecules that play an important role in the redox landscape, such as nicotinamide adenine dinucleotide (NADH) [126]. Furthermore, a recent study presented redox sensors for the cytosolic glutathione system, the major antioxidant system of the cell [127]. These genetically encoded redox proteins are very useful for monitoring the redox landscape under experimental conditions [128]. For instance, these sensors enable the study of molecular pathologies in animal models, such as the oxidative stress-mediated neurodegeneration of motor neurons in zebrafish [129]. Unfortunately, redox protein sensors depend on specific model systems, which prevents their application for diagnostic or therapeutic purposes in the human patient.

By contrast, redox sensors based on small molecules can be applied theoretically to humans, since the administration of compounds is not restricted to a defined model organism. Some recent examples include nicotinamide molecules that are conjugated to fluorophores, and serve as effective redox sensors in biological systems [130]. Other advances are multichannel redox sensors that combine chromogenic, fluorescent, and electrochemical signals for monitoring intracellular $\mathrm{H}_{2} \mathrm{O}_{2}$ in vivo [131]. However, small-molecule-based redox sensors require a specific chemical interaction between the compound and the target molecule; hence, their application is limited by the availability, selectivity, reversibility, and kinetics of the sensing reaction [123].

Besides the development of novel tools, another promising path for monitoring redox states in cellular model systems is the improvement of imaging devices. One recent example is the development of fluorescence lifetime imaging microscopy for single-cell ROS detection (FLIM-ROX) [132]. FLIM has been used before to detect the redox state in cells via reduction of NADH; however, the authors of this study applied FLIM in conjunction with selected ROS reporter dyes. The combination of the dye with the microscopic technique improved the sensitivity and reliability of ROS detection in lifetime imaging.

Research also explores some entirely novel approaches for monitoring oxidative stress in biological systems. A very recent and highly innovative approach to study the redox landscape in vivo in real-time was presented by Baltsavias et al. [133]. This group developed a small implant that is capable of measuring the balance of oxidants and reductants that are produced by the interplay of host, microbe, and diet in the gut. After implanting in rats, the device was powered externally with ultrasonic waves, and was able to monitor the redox state in the gut of the living animal for almost two weeks. This approach enables long-term experimental testing of redox pathophysiology mechanisms, and facilitates translation to disease diagnosis and treatment applications in the future.

\subsection{Positron Emission Tomography (PET) for Monitoring Oxidative Stress}

Noninvasive imaging methods provide diagnostic and prognostic information on functional states of the brain, and support effectivity assessment of new drug candidates $[134,135]$. Positron emission tomography (PET) is a molecular imaging modality, in which the administration of a positron emission radiotracer enables visualization and quantification of biochemical processes in vivo [136]. In neuroimaging, this radiotracer is often a small molecule that is labeled with fluorine-18 (half-life of $109.8 \mathrm{~min}$ ) or carbon-11 (half-life of $20.3 \mathrm{~min}$ ) radionuclides. An ideal PET radiotracer displays a high signal-to- 
noise ratio, which is defined as the ratio of specific to nonspecific binding, and increases its signal under a pathological versus a baseline (i.e., physiological) condition. Ideally, this signal also correlates with disease severity and responds to known therapeutic agents.

One proposed strategy for detecting ROS using PET relies on the change in cell permeability of dihydroethidium (DHT) tracers upon oxidation. A neutral fluorine-18 labelled DHT analog is BBB permeable, and becomes positively charged upon reacting with $\mathrm{O}_{2}{ }^{\bullet-}$, trapping it intracellularly [137]. In a lipopolysaccharide (LPS) lesion model, this tracer showed enhanced accumulation in the ipsilateral side of the mouse brain, and the PET signal intensity correlated with the severity of the clinical symptoms [138]. Another family of $\mathrm{O}_{2}{ }^{\bullet-}$ sensitive PET tracers is based on the dihydroisoquinoline scaffold. A carbon-11 labeled hydromethidine was initially described to accumulate in the rat brain after a LPS injury [139]. A fluorine-18 analog recently confirmed the retention of the tracer in the affected region [140]. However, this strategy detects only intracellular ROS, since the cationized tracer is only retained if formed inside the cell.

A notable study explored the differential uptake kinetics of oxidized versus reduced ascorbic acid, and overcame this limitation [141]. Ascorbic acid was labeled with carbon-11, and, after reacting with $\mathrm{H}_{2} \mathrm{O}_{2}$ or $\mathrm{O}_{2}{ }^{\bullet-}$, it yielded $\left[{ }^{11} \mathrm{C}\right]$ dehydroascorbic acid $\left(\left[{ }^{11} \mathrm{C}\right] \mathrm{DHA}\right)$, which is transported to cells ten times faster than ascorbic acid. Differential uptake of $\left[{ }^{11} \mathrm{C}\right] \mathrm{DHA}$ was demonstrated in both cancer cell lines and also in human neutrophils, validating this approach. Another way of detecting extracellular ROS with PET focuses on the equilibrative nucleoside transporter 1 (ENT1). Here, the endogenous thymidine substrate was modified with a $\mathrm{H}_{2} \mathrm{O}_{2}$ carbamate-boronate-sensitive linker, and labeled with fluorine-18. Upon reaction with $\mathrm{H}_{2} \mathrm{O}_{2}$, the linker decomposes, making it a better substrate for ENT1-mediated internalization. Once inside the cell, the thymidine substrate cannot be further metabolized because of the fluorine-18 modification, which impairs enzyme recognition, eventually leading to intracellular tracer accumulation [142]. As a note, this tracer is also cell-permeable via passive diffusion and, hence, reports both intraand extracellular ROS. The tracer signal responded to $\mathrm{H}_{2} \mathrm{O}_{2}$ dose-dependently, and was blocked by co-incubation with high concentrations of thymidine. However, the described applications were limited to cellular carcinoma models, perhaps due to the carbonate linker instability in vivo.

Only a few PET tracers were used in clinical studies to specifically probe redox processes in vivo. One of them is the copper chelator $\left[{ }^{62 / 64} \mathrm{Cu}\right] \mathrm{Cu}$-ATSM. After reacting with ROS, the reduced radioactive ${ }^{62 / 64} \mathrm{Cu}^{+}$dissociates from the complex, and is retained in the tissue [143]. This tracer was also applied in neurodegenerative diseases, such as Parkinson's disease and amyotrophic lateral sclerosis (ALS), as well as in cancer $[124,144]$. Unlike the previously described tracers, which are reactive toward endogenous ROS, the $\left[{ }^{18} \mathrm{~F}\right]$ fluoropropyl-glutamate tracer $\left[{ }^{18} \mathrm{~F}\right] \mathrm{FSPG}$ provides a measure of cellular antioxidant response via imaging a major contributor to the cellular redox homeostasis, i.e., the cystine/glutamate antiporter system $\mathrm{x}_{\mathrm{C}}{ }^{-} \cdot\left[{ }^{18} \mathrm{~F}\right] \mathrm{FSPG}$ is a substrate of system $\mathrm{x}_{\mathrm{C}}{ }^{-}$, and cancer cells under oxidative stress upregulate this transporter, which is expressed at a low level in normal cells $[145,146]$. In a recent clinical trial, $\left[{ }^{18} \mathrm{~F}\right]$ FSPG PET was used for the diagnosis of prostate cancer, confirming the high signalto-background uptake levels [147]. Interestingly, this tracer was employed previously to detect the inflammatory component of the autoimmune disease sarcoidosis, even though it did not outperform the sugar analog $\left[{ }^{18} \mathrm{~F}\right] \mathrm{FDG}$, which is routinely applied in PET [148].

\section{Imaging Redox Biomarkers of Neuroinflammation in the Clinic}

Several biomarkers and associated radiotracers were proposed for the detection of different steps in the neuroinflammation biochemical cascade. We refer the interested reader to two detailed and comprehensive overviews of recent neuroinflammation PET biomarkers [149,150]. Here, we provide a brief overview of two imaging biomarkers for neuroinflammation, which are linked to the redox landscape: TSPO and MAO-B (Figure 3). Both imaging biomarkers play 
an important role in the cellular redox landscape, and are associated with clinically validated tracers. TSPO is involved in mitochondrial activity, whereas MAO-B generates $\mathrm{H}_{2} \mathrm{O}_{2}$ in the mitochondria $[151,152]$. As of now, PET is one of the few methods that warrants adequate sensitivity for measuring the abundance of transiently expressed redox-related biomarkers of neuroinflammation with translational potential.
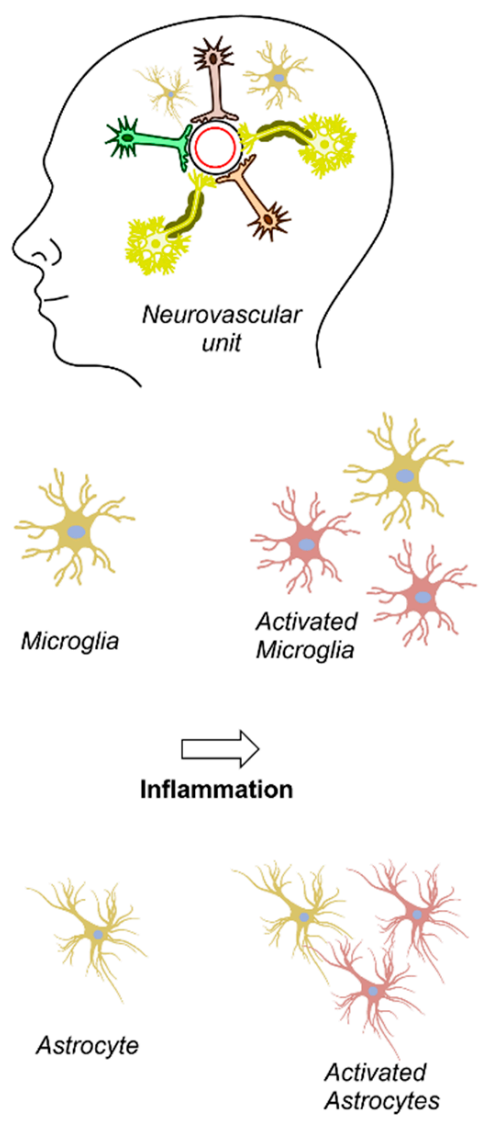
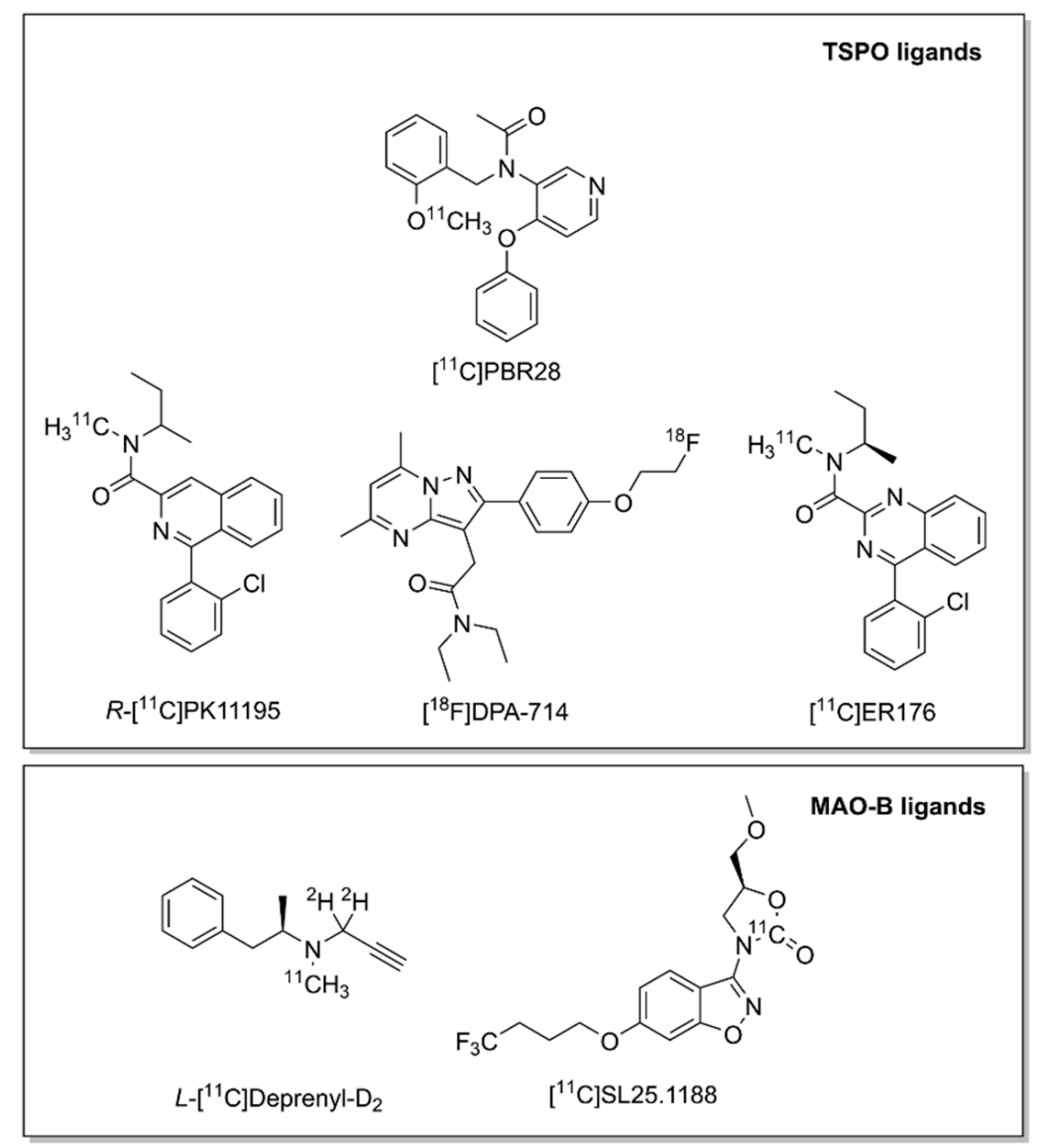

Figure 3. Positron emission tomography (PET) radioligands for translational molecular imaging of two biomarkers of neuroinflammation. The $18 \mathrm{kDa}$ translocator protein (TSPO) and the enzyme monoamine oxidase B (MAO-B) are overexpressed in response to inflammation predominately in microglia and astrocytes, respectively.

\subsection{Translocator Protein (TSPO)}

TSPO, also known as peripheral benzodiazepine receptor (PBR), is an abundantly expressed protein that is mainly located in the mitochondria, where it acts as a cholesterol transporter protein [153]. Notably, TSPO plays an important role in the amplification of ROS in the mitochondria $[151,154]$. The expression of TSPO in microglia is significantly upregulated upon injury or inflammation in the brain [155]. Since basal TSPO expression in the CNS is low, its upregulation indicates CNS infiltration and activation of immune cells in the brain [156]. TSPO was the first neuroinflammation biomarker for PET radiotracers, and it is still the most explored target.

Currently, three generations of TSPO PET ligands exist. The first contains the carbon11-labeled isoquinoline $\left[{ }^{11} \mathrm{C}\right] \mathrm{PK} 11195$. This molecule was discovered in the early 1980s and was described as binding to a peripheral benzodiazepine-binding site of the $\gamma$-aminobutyric acid (GABA) receptor, which corresponds to TSPO, as later studies demonstrated [157,158]. Early preclinical reports showed that racemic PK11195 binds in ischemic lesions in rats, and that the $R$-isomer tracer binding is 2-fold higher than the $S$-analog [159]. A subsequent clinical study using the $R$-enantiomer of PK11195 demonstrated that high levels of tracer accumulated at pathological sites in MS and, according to magnetic resonance imaging 
(MRI), in normal-appearing white-matter regions, as well [160]. This study also explained the $R-\left[{ }^{11} \mathrm{C}\right] \mathrm{PK} 11195$ signal increase by a high number of binding sites, and excluded the possibility of an altered affinity toward TSPO. Nonetheless, additional studies indicated poor pharmacokinetics, low brain uptake, and high nonspecific binding levels, which still poses a challenge for quantification and modeling of $R-\left[{ }^{11} \mathrm{C}\right] \mathrm{PK} 11195$ uptake in pathological brain areas [161].

A second-generation of TSPO ligands was developed, including pyrazolopyrimidine tracers labeled with fluorine-18, and eventually compared with [ $\left.{ }^{11} \mathrm{C}\right] \mathrm{PK} 11195$ in a rat model of neuroinflammation. For example, $\left[{ }^{18} \mathrm{~F}\right] \mathrm{DPA}-714$ accumulation in the ipsilateral side to the lesion was five-times higher than $R-\left[{ }^{11} \mathrm{C}\right] \mathrm{PK} 11195$, and demonstrated lower nonspecific binding [162]. In 2012, the discovery of a single nucleotide mutation in the human TSPO gene finally explained the high inter-individual variability that clinical trials with secondgeneration TSPO ligands had observed previously [163]. Patient stratification prior to the clinical trials may overcome this issue; however, this observed genetic variability still limits the application of TSPO as a biomarker for neuroinflammation and hampers patient enrollment.

Currently, efforts are underway in designing and developing a third generation of TSPO ligands that specifically address the differential response due to TSPO polymorphisms [164]. Nevertheless, it is still unclear whether these compounds will match the requirements that are needed for irrevocable radioligands for PET imaging of activated microglia.

Despite the challenges of TSPO imaging, numerous clinical trials confirmed that all three generations of TSPO PET tracer are able to delineate brain neuroinflammation $[165,166]$. TSPO imaging has been used to track disease severity and the efficacy of treatments in neurodegenerative disorders, such as Alzheimer's disease and dementia $[167,168]$. A recent study showed a reduction in binding of the first-generation $R-\left[{ }^{11} \mathrm{C}\right] \mathrm{PK} 11195$ tracer in the brain of patients with MS after treatment with the therapeutic antibody Natalizumab [169]. Importantly, high PET signals in white-matter regions correlated with more rapidly progressing disease after four years of imaging, which indicates the prognostic value of this tracer. Another clinical study on MS demonstrated that binding of the second-generation tracer $\left[{ }^{11} \mathrm{C}\right] \mathrm{PBR} 28$ correlated with deteriorating cognitive performance and neurological scores [170]. This study further highlighted the benefits of PET imaging, in particular, since morphologically normal-appearing white matter produced abnormally high $\left[{ }^{11} \mathrm{C}\right] \mathrm{PBR} 28$ signal.

Even though TSPO imaging of neuroinflammation has not yet reached routine clinical applications, an extensive number of clinical studies confirmed the correlation of TSPO upregulation with in vivo glial activation, disease symptom severity, and, in some cases, with disease prognosis.

\subsection{Monoamine Oxidase B (MAO-B)}

Despite the progress on TSPO ligands over the years, the work on preclinical models pointed out the advantages of other neuroinflammation biomarkers in diseases, such as $\mathrm{AD}$ and MS [171]. One of these proposed new targets is the enzyme MAO-B.

$\mathrm{MAO}-\mathrm{B}$ is expressed in mitochondria, and is an important component of the cellular redox landscape in the brain $[172,173]$. The enzyme produces $\mathrm{H}_{2} \mathrm{O}_{2}$, modulates oxidative stress, and, hence, contributes to inflammation [174]. In the brain, MAO-B is located mainly in the outer mitochondrial membrane of astrocytes and neurons [175]. Certain diseases, such as AD or ALS, are associated with an increased number of activated astrocytes, which correlates with MAO-B expression. Overexpressed MAO-B also colocalizes with the astrocyte marker glial fibrillary acidic protein (GFAP).

Molecular imaging agents that target MAO-B have been known since the late1980s [176]. The first class of PET tracers are based on suicide inhibitors that contain an acetylenic residue for binding to the flavin group at the active site of $\mathrm{MAO}-$ $B$ [177]. In the brain, the signal from L- $\left[{ }^{11} \mathrm{C}\right]$ deprenyl and its more recent deuterated 
form L- $\left[{ }^{11} \mathrm{C}\right]$ deprenyl- $\mathrm{D}_{2}$ is sensitive to pharmacological modulation, which correlates reproducibly with the distribution of MAO-B in humans [178-180]. However, tracer modeling is challenging, since this class of ligands is metabolically converted to methamphetamine, which is brain-penetrant and pharmacologically active [181,182].

Novel ligands, such as the oxazolidinone $\left[{ }^{11} \mathrm{C}\right]$ SL25.1188, are promising tracers with reversible and high-affinity binding for MAO-B [183]. In baboons, $\left[{ }^{11} \mathrm{C}\right]$ SL25.1188 showed no formation of brain-penetrant metabolites, was eliminated faster than L- $\left[{ }^{11} \mathrm{C}\right]$ deprenyl- $\mathrm{D}_{2}$, and its signal correlated with MAO-B distribution [184]. Kinetic modeling of $\left[{ }^{11} \mathrm{C}\right] S L 25.1188$ confirmed the favorable pharmacokinetics and paved the way for this tracer as an imaging biomarker for MAO-B [185]. As of now, the disease relevance of $\left[{ }^{11} \mathrm{C}\right] \mathrm{SL} 25.1188$ has been studied only in patients with major depressive disorder (MDD) [186]. In these studies, the tracer levels were $25 \%$ higher in the prefrontal cortex of MDD patients than in healthy controls. This suggests a new pathophysiological hypothesis for depression that involves mitochondrial dysfunction or monoamine metabolism imbalance.

\subsection{Recent Examples of PET Imaging of Neuroinflammatory Biomarkers in Stroke and Alzheimer's Disease}

Ischemic stroke pathology entails a very dynamic and acute neuroinflammatory component with multiple molecular hallmarks within different parts of the brain. Currently, imaging methods pinpoint the location, extension, and type of the stroke lesion, and they estimate penumbral regions, i.e., potentially salvageable brain regions surrounding the primary lesion [187]. TSPO PET imaging revealed a slow increase in tracer uptake localized in the periphery of the main lesion until the third day after stroke. Then, a sudden rise in TSPO signal occurs and peaks after two weeks, also spreading into the core lesion. After this time, the tracer levels at the ischemic core decline but reach later areas remote from the initial stroke site [188]. Neuroinflammation imaging may guide and tailor therapeutics to timely induce inflammatory tissue repair or to reduce global inflammatory mechanisms [189].

In the case of $\mathrm{AD}$, PET molecular imaging has already contributed to the diagnostics of two classical hallmarks: A $\beta$ plaques and neurofibrillary tangles (NFTs) [190]. PET molecular imaging also provided compelling evidence for the presence of an underlying chronic inflammatory component (reviewed in [191] and [192]) of AD. A multitracer study tracked the associated inflammatory processes, and shed light on the complex pathophysiology of AD. $R-\left[{ }^{11} \mathrm{C}\right] \mathrm{PK} 11195$, combined with tracers for $\mathrm{A} \beta$ and tau protein, revealed a biphasic neuroinflammation pattern in AD patients: initially, the $R-\left[{ }^{11} \mathrm{C}\right] \mathrm{PK} 11195$ signal was high in subjects bearing low $A \beta$ levels and mild cognitive impairment (MCI) but, eventually, $R-\left[{ }^{11} \mathrm{C}\right] \mathrm{PK} 11195$ levels decreased as $\mathrm{A} \beta$ loads rose to pathological levels. At this later phase, the tau protein levels increased, and prompted the second wave of microglial activation, reaching the pathological phenotype of concomitant high levels of $A \beta$ and tau protein and cognitive deterioration [193]. Similarly, the signal of the secondgeneration TSPO tracer $\left[{ }^{11} \mathrm{C}\right]$ PBR28 was elevated in more than $50 \mathrm{MCI}$ patients, potentially indicating a protective microglial activation at early AD [194]. In a remarkable longitudinal study, patients with genetic predisposition for $A D$ were scanned for both $A \beta$ and $M A O-B$ using L- $\left[{ }^{11} \mathrm{C}\right]$ deprenyl- $\mathrm{D}_{2}$. The images showed high levels of astrocytosis in asymptomatic subjects initially, which steadily declined over the course of two to three years. Moreover, the PET signal was also elevated in patients carrying autosomal-dominant $\mathrm{AD}$ mutations, even seventeen years before the expected onset of symptoms, which provides a window for AD early diagnosis [195].

\section{Conclusions}

A growing body of research provides evidence that inflammation in the brain is a driving force in the development of many human diseases. Research on the molecular events of brain inflammation, in particular its redox component, is a challenging endeavor, due to the high complexity of the inflammatory process and the brief lifetime of redox molecules. In addition, the seclusion of the brain (and the CNS) from the blood circulation 
by the BBB hampers the discovery of biomarkers and the development of novel therapeutic compounds for effective therapeutic intervention. Furthermore, the lack of tools to monitor and visualize the dynamic states of brain inflammation in the patient accounts for inadequate diagnostic options in many neurological disorders.

The recent advent of chemical biology provides medical professionals with the proper means for diagnostics, and scientists with an increasing arsenal of tools to elucidate the underlying molecular basis of inflammatory brain diseases. Chemical biology and diagnostic tools will further push the boundaries of our understanding and the success of medical interventions. Given the increasing incidence of inflammatory brain diseases, such as stroke and $\mathrm{AD}$, these developments are urgently needed.

Author Contributions: D.Ö. conceptualized, planned, and supervised the work; E.F.A.F. and D.Ö. retrieved information, designed figures, and wrote and edited the draft. Both authors read and agreed to the published version of the manuscript.

Funding: This work received no external funding.

Information Retrieval: Literature was retrieved by searching the main databases PubMed and Scopus, as well as Google Scholar, Google Search, and Web of Science; references were managed using Endnote X8.2 (Clarivate, Philadelphia, PA, USA); figures were created using Inkscape 0.92 (Software Freedom Conservancy, Brooklyn, NY, USA), and ChemDraw Professional 19.1 (PerkinElmer, Inc., Waltham, MA, USA).

Acknowledgments: The authors thank Madeleine Ernst and Sana Ma for critically reading the manuscript.

Conflicts of Interest: The authors declare no conflict of interest.

\section{References}

1. Yuan, N.; Chen, Y.; Xia, Y.; Dai, J.; Liu, C. Inflammation-related biomarkers in major psychiatric disorders: A cross-disorder assessment of reproducibility and specificity in 43 meta-analyses. Transl. Psychiatry 2019, 9, 233. [CrossRef]

2. Radtke, F.A.; Chapman, G.; Hall, J.; Syed, Y.A. Modulating Neuroinflammation to Treat Neuropsychiatric Disorders. Biomed. Res. Int. 2017, 2017, 5071786. [CrossRef] [PubMed]

3. Meyer, J.H.; Cervenka, S.; Kim, M.J.; Kreisl, W.C.; Henter, I.D.; Innis, R.B. Neuroinflammation in psychiatric disorders: PET imaging and promising new targets. Lancet Psychiatry 2020, 7, 1064-1074. [CrossRef]

4. Matthews, P.M. Chronic inflammation in multiple sclerosis-Seeing what was always there. Nat. Rev. Neurol. 2019, 15, 582-593. [CrossRef] [PubMed]

5. Vaughn, C.B.; Jakimovski, D.; Kavak, K.S.; Ramanathan, M.; Benedict, R.H.B.; Zivadinov, R.; Weinstock-Guttman, B. Epidemiology and treatment of multiple sclerosis in elderly populations. Nat. Rev. Neurol. 2019, 15, 329-342. [CrossRef] [PubMed]

6. Thompson, A.J.; Baranzini, S.E.; Geurts, J.; Hemmer, B.; Ciccarelli, O. Multiple sclerosis. Lancet 2018, 391, 1622-1636. [CrossRef]

7. Scheltens, P.; Blennow, K.; Breteler, M.M.; de Strooper, B.; Frisoni, G.B.; Salloway, S.; Van der Flier, W.M. Alzheimer's disease. Lancet 2016, 388, 505-517. [CrossRef]

8. Kinney, J.W.; Bemiller, S.M.; Murtishaw, A.S.; Leisgang, A.M.; Salazar, A.M.; Lamb, B.T. Inflammation as a central mechanism in Alzheimer's disease. Alzheimers Dement. 2018, 4, 575-590. [CrossRef] [PubMed]

9. Heneka, M.T.; Carson, M.J.; El Khoury, J.; Landreth, G.E.; Brosseron, F.; Feinstein, D.L.; Jacobs, A.H.; Wyss-Coray, T.; Vitorica, J.; Ransohoff, R.M.; et al. Neuroinflammation in Alzheimer's disease. Lancet Neurol. 2015, 14, 388-405. [CrossRef]

10. Schwab, C.; Klegeris, A.; McGeer, P.L. Inflammation in transgenic mouse models of neurodegenerative disorders. Biochim. Biophys. Acta 2010, 1802, 889-902. [CrossRef]

11. Park, J.C.; Han, S.H.; Mook-Jung, I. Peripheral inflammatory biomarkers in Alzheimer's disease: A brief review. BMB Rep. 2020, 53, 10-19. [CrossRef]

12. Ng, A.; Tam, W.W.; Zhang, M.W.; Ho, C.S.; Husain, S.F.; McIntyre, R.S.; Ho, R.C. IL-1beta, IL-6, TNF- alpha and CRP in Elderly Patients with Depression or Alzheimer's disease: Systematic Review and Meta-Analysis. Sci. Rep. 2018, 8, 12050. [CrossRef] [PubMed]

13. Hur, J.Y.; Frost, G.R.; Wu, X.; Crump, C.; Pan, S.J.; Wong, E.; Barros, M.; Li, T.; Nie, P.; Zhai, Y.; et al. The innate immunity protein IFITM3 modulates gamma-secretase in Alzheimer's disease. Nature 2020, 586, 735-740. [CrossRef]

14. Baruch, K.; Deczkowska, A.; David, E.; Castellano, J.M.; Miller, O.; Kertser, A.; Berkutzki, T.; Barnett-Itzhaki, Z.; Bezalel, D.; Wyss-Coray, T.; et al. Aging. Aging-induced type I interferon response at the choroid plexus negatively affects brain function. Science 2014, 346, 89-93. [CrossRef]

15. Turnbull, I.R.; Gilfillan, S.; Cella, M.; Aoshi, T.; Miller, M.; Piccio, L.; Hernandez, M.; Colonna, M. Cutting edge: TREM-2 attenuates macrophage activation. J. Immunol. 2006, 177, 3520-3524. [CrossRef] 
16. Zheng, H.; Liu, C.C.; Atagi, Y.; Chen, X.F.; Jia, L.; Yang, L.; He, W.; Zhang, X.; Kang, S.S.; Rosenberry, T.L.; et al. Opposing roles of the triggering receptor expressed on myeloid cells 2 and triggering receptor expressed on myeloid cells-like transcript 2 in microglia activation. Neurobiol. Aging 2016, 42, 132-141. [CrossRef]

17. Bouchon, A.; Hernandez-Munain, C.; Cella, M.; Colonna, M. A DAP12-mediated pathway regulates expression of CC chemokine receptor 7 and maturation of human dendritic cells. J. Exp. Med. 2001, 194, 1111-1122. [CrossRef]

18. Bhattacharjee, S.; Zhao, Y.; Dua, P.; Rogaev, E.I.; Lukiw, W.J. microRNA-34a-Mediated Down-Regulation of the MicroglialEnriched Triggering Receptor and Phagocytosis-Sensor TREM2 in Age-Related Macular Degeneration. PLoS ONE 2016, 11, e0150211. [CrossRef] [PubMed]

19. Shi, Y.; Holtzman, D.M. Interplay between innate immunity and Alzheimer disease: APOE and TREM2 in the spotlight. Nat. Rev. Immunol. 2018, 18, 759-772. [CrossRef] [PubMed]

20. Campbell, B.C.V.; Khatri, P. Stroke. Lancet 2020, 396, 129-142. [CrossRef]

21. Sommer, C.J. Ischemic stroke: Experimental models and reality. Acta Neuropathol. 2017, 133, 245-261. [CrossRef]

22. He, Z.; Ning, N.; Zhou, Q.; Khoshnam, S.E.; Farzaneh, M. Mitochondria as a therapeutic target for ischemic stroke. Free Radic. Biol. Med. 2020, 146, 45-58. [CrossRef]

23. Jones, D.P.; Sies, H. The Redox Code. Antioxid. Redox Signal. 2015, 23, 734-746. [CrossRef] [PubMed]

24. Sies, H.; Berndt, C.; Jones, D.P. Oxidative Stress. Annu. Rev. Biochem. 2017, 86, 715-748. [CrossRef]

25. Jena, N.R. DNA damage by reactive species: Mechanisms, mutation and repair. J. Biosci. 2012, 37, 503-517. [CrossRef] [PubMed]

26. Berlett, B.S.; Stadtman, E.R. Protein oxidation in aging, disease, and oxidative stress. J. Biol. Chem. 1997, 272, 20313-20316. [CrossRef]

27. Redza-Dutordoir, M.; Averill-Bates, D.A. Activation of apoptosis signalling pathways by reactive oxygen species. Biochim. Biophys. Acta 2016, 1863, 2977-2992. [CrossRef] [PubMed]

28. Naik, E.; Dixit, V.M. Mitochondrial reactive oxygen species drive proinflammatory cytokine production. J. Exp. Med. 2011, 208, 417-420. [CrossRef]

29. McEwen, B.S. Protective and damaging effects of stress mediators: Central role of the brain. Dialogues Clin. Neurosci. 2006, 8, 367-381.

30. Jackson, P.A.; Pialoux, V.; Corbett, D.; Drogos, L.; Erickson, K.I.; Eskes, G.A.; Poulin, M.J. Promoting brain health through exercise and diet in older adults: A physiological perspective. J. Physiol. 2016, 594, 4485-4498. [CrossRef]

31. Niewada, M.; Michel, P. Lifestyle modification for stroke prevention: Facts and fiction. Curr. Opin. Neurol. 2016, 29, 9-13. [CrossRef] [PubMed]

32. Galimanis, A.; Mono, M.L.; Arnold, M.; Nedeltchev, K.; Mattle, H.P. Lifestyle and stroke risk: A review. Curr. Opin. Neurol. 2009, 22, 60-68. [CrossRef]

33. Altobelli, E.; Angeletti, P.M.; Rapacchietta, L.; Petrocelli, R. Overview of Meta-Analyses: The Impact of Dietary Lifestyle on Stroke Risk. Int. J. Environ. Res. Public Health 2019, 16, 3582. [CrossRef]

34. Popa-Wagner, A.; Dumitrascu, D.I.; Capitanescu, B.; Petcu, E.B.; Surugiu, R.; Fang, W.H.; Dumbrava, D.A. Dietary habits, lifestyle factors and neurodegenerative diseases. Neural Regen. Res. 2020, 15, 394-400. [CrossRef]

35. Madore, C.; Yin, Z.; Leibowitz, J.; Butovsky, O. Microglia, Lifestyle Stress, and Neurodegeneration. Immunity 2020, 52, 222-240. [CrossRef]

36. Ruiz-Nunez, B.; Pruimboom, L.; Dijck-Brouwer, D.A.; Muskiet, F.A. Lifestyle and nutritional imbalances associated with Western diseases: Causes and consequences of chronic systemic low-grade inflammation in an evolutionary context. J. Nutr. Biochem. 2013, 24, 1183-1201. [CrossRef] [PubMed]

37. Mintzer, J.; Donovan, K.A.; Kindy, A.Z.; Lock, S.L.; Chura, L.R.; Barracca, N. Lifestyle Choices and Brain Health. Front. Med. 2019, 6, 204. [CrossRef] [PubMed]

38. Dando, S.J.; Mackay-Sim, A.; Norton, R.; Currie, B.J.; St John, J.A.; Ekberg, J.A.; Batzloff, M.; Ulett, G.C.; Beacham, I.R. Pathogens penetrating the central nervous system: Infection pathways and the cellular and molecular mechanisms of invasion. Clin. Microbiol. Rev. 2014, 27, 691-726. [CrossRef] [PubMed]

39. Simon, D.W.; McGeachy, M.J.; Bayir, H.; Clark, R.S.; Loane, D.J.; Kochanek, P.M. The far-reaching scope of neuroinflammation after traumatic brain injury. Nat. Rev. Neurol. 2017, 13, 171-191. [CrossRef]

40. Suzuki, T.; Hidaka, T.; Kumagai, Y.; Yamamoto, M. Environmental pollutants and the immune response. Nat. Immunol. 2020, 21, 1486-1495. [CrossRef]

41. Sharma, R.K.; Agrawal, M. Biological effects of heavy metals: An overview. J. Environ. Biol. 2005, 26, 301-313.

42. Patel, S.; Sangeeta, S. Pesticides as the drivers of neuropsychotic diseases, cancers, and teratogenicity among agro-workers as well as general public. Environ. Sci. Pollut. Res. Int. 2019, 26, 91-100. [CrossRef]

43. Lee, G.H.; Choi, K.C. Adverse effects of pesticides on the functions of immune system. Comp. Biochem. Physiol. C Toxicol. Pharmacol. 2020, 235, 108789. [CrossRef] [PubMed]

44. Gangemi, S.; Gofita, E.; Costa, C.; Teodoro, M.; Briguglio, G.; Nikitovic, D.; Tzanakakis, G.; Tsatsakis, A.M.; Wilks, M.F.; Spandidos, D.A.; et al. Occupational and environmental exposure to pesticides and cytokine pathways in chronic diseases (Review). Int. J. Mol. Med. 2016, 38, 1012-1020. [CrossRef] [PubMed]

45. Li, B.; Ding, Y.; Cheng, X.; Sheng, D.; Xu, Z.; Rong, Q.; Wu, Y.; Zhao, H.; Ji, X.; Zhang, Y. Polyethylene microplastics affect the distribution of gut microbiota and inflammation development in mice. Chemosphere 2020, 244, 125492. [CrossRef] 
46. Hwang, J.; Choi, D.; Han, S.; Jung, S.Y.; Choi, J.; Hong, J. Potential toxicity of polystyrene microplastic particles. Sci. Rep. 2020, 10, 7391. [CrossRef]

47. Jayaraj, R.L.; Rodriguez, E.A.; Wang, Y.; Block, M.L. Outdoor Ambient Air Pollution and Neurodegenerative Diseases: The Neuroinflammation Hypothesis. Curr. Environ. Health Rep. 2017, 4, 166-179. [CrossRef] [PubMed]

48. Block, M.L.; Calderon-Garciduenas, L. Air pollution: Mechanisms of neuroinflammation and CNS disease. Trends Neurosci. 2009, 32, 506-516. [CrossRef]

49. Babadjouni, R.M.; Hodis, D.M.; Radwanski, R.; Durazo, R.; Patel, A.; Liu, Q.; Mack, W.J. Clinical effects of air pollution on the central nervous system; a review. J. Clin. Neurosci. 2017, 43, 16-24. [CrossRef]

50. Calderon-Garciduenas, L.; Gonzalez-Maciel, A.; Reynoso-Robles, R.; Hammond, J.; Kulesza, R.; Lachmann, I.; Torres-Jardon, R.; Mukherjee, P.S.; Maher, B.A. Quadruple abnormal protein aggregates in brainstem pathology and exogenous metal-rich magnetic nanoparticles (and engineered Ti-rich nanorods). The substantia nigrae is a very early target in young urbanites and the gastrointestinal tract a key brainstem portal. Environ. Res. 2020, 191, 110139. [CrossRef] [PubMed]

51. Medzhitov, R. Origin and physiological roles of inflammation. Nature 2008, 454, 428-435. [CrossRef]

52. Turner, M.D.; Nedjai, B.; Hurst, T.; Pennington, D.J. Cytokines and chemokines: At the crossroads of cell signalling and inflammatory disease. Biochim. Biophys. Acta 2014, 1843, 2563-2582. [CrossRef]

53. Kany, S.; Vollrath, J.T.; Relja, B. Cytokines in Inflammatory Disease. Int. J. Mol. Sci. 2019, 20, 6008. [CrossRef]

54. Forrester, S.J.; Kikuchi, D.S.; Hernandes, M.S.; Xu, Q.; Griendling, K.K. Reactive Oxygen Species in Metabolic and Inflammatory Signaling. Circ. Res. 2018, 122, 877-902. [CrossRef]

55. Mittal, M.; Siddiqui, M.R.; Tran, K.; Reddy, S.P.; Malik, A.B. Reactive oxygen species in inflammation and tissue injury. Antioxid. Redox Signal. 2014, 20, 1126-1167. [CrossRef] [PubMed]

56. Schieber, M.; Chandel, N.S. ROS function in redox signaling and oxidative stress. Curr. Biol. 2014, 24, R453-R462. [CrossRef]

57. Sies, H.; Jones, D.P. Reactive oxygen species (ROS) as pleiotropic physiological signalling agents. Nat. Rev. Mol. Cell Biol. 2020, 21, 363-383. [CrossRef] [PubMed]

58. Dickinson, B.C.; Chang, C.J. Chemistry and biology of reactive oxygen species in signaling or stress responses. Nat. Chem. Biol. 2011, 7, 504-511. [CrossRef]

59. Yoboue, E.D.; Sitia, R.; Simmen, T. Redox crosstalk at endoplasmic reticulum (ER) membrane contact sites (MCS) uses toxic waste to deliver messages. Cell Death Dis. 2018, 9. [CrossRef]

60. Boveris, A.; Oshino, N.; Chance, B. The cellular production of hydrogen peroxide. Biochem. J. 1972, 128, 617-630. [CrossRef] [PubMed]

61. Reczek, C.R.; Chandel, N.S. ROS-dependent signal transduction. Curr. Opin. Cell Biol. 2015, 33, 8-13. [CrossRef] [PubMed]

62. Narayanan, D.; Ma, S.N.; Ozcelik, D. Targeting the Redox Landscape in Cancer Therapy. Cancers 2020, 12, 1706. [CrossRef] [PubMed]

63. Sies, H. Oxidative stress: A concept in redox biology and medicine. Redox Biol. 2015, 4, 180-183. [CrossRef] [PubMed]

64. Oberkampf, M.; Guillerey, C.; Mouries, J.; Rosenbaum, P.; Fayolle, C.; Bobard, A.; Savina, A.; Ogier-Denis, E.; Enninga, J.; Amigorena, S.; et al. Mitochondrial reactive oxygen species regulate the induction of CD8(+) T cells by plasmacytoid dendritic cells. Nat. Commun. 2018, 9, 2241. [CrossRef]

65. Holmdahl, R.; Sareila, O.; Pizzolla, A.; Winter, S.; Hagert, C.; Jaakkola, N.; Kelkka, T.; Olsson, L.M.; Wing, K.; Backdahl, L. Hydrogen peroxide as an immunological transmitter regulating autoreactive T cells. Antioxid. Redox Signal. 2013, 18, 1463-1474. [CrossRef] [PubMed]

66. Matsukawa, J.; Matsuzawa, A.; Takeda, K.; Ichijo, H. The ASK1-MAP kinase cascades in mammalian stress response. J. Biochem. 2004, 136, 261-265. [CrossRef]

67. Lee, K.; Esselman, W.J. cAMP potentiates $\mathrm{H}_{2} \mathrm{O}_{2}$-induced ERK1/2 phosphorylation without the requirement for MEK1/2 phosphorylation. Cell Signal. 2001, 13, 645-652. [CrossRef]

68. Cargnello, M.; Roux, P.P. Activation and function of the MAPKs and their substrates, the MAPK-activated protein kinases. Microbiol. Mol. Biol. Rev. 2011, 75, 50-83. [CrossRef]

69. Yin, J.; Duan, J.L.; Cui, Z.J.; Ren, W.K.; Li, T.J.; Yin, Y.L. Hydrogen peroxide-induced oxidative stress activates NF-kappa B and Nrf2/Keap1 signals and triggers autophagy in piglets. Rsc Adv. 2015, 5, 15479-15486. [CrossRef]

70. Morgan, M.J.; Liu, Z.G. Crosstalk of reactive oxygen species and NF-kappaB signaling. Cell Res. 2011, 21, 103-115. [CrossRef]

71. Christian, F.; Smith, E.L.; Carmody, R.J. The Regulation of NF-kappaB Subunits by Phosphorylation. Cells 2016, 5, 12. [CrossRef]

72. Luo, B.; Wang, J.; Liu, Z.; Shen, Z.; Shi, R.; Liu, Y.Q.; Liu, Y.; Jiang, M.; Wu, Y.; Zhang, Z. Phagocyte respiratory burst activates macrophage erythropoietin signalling to promote acute inflammation resolution. Nat. Commun. 2016, 7, 12177. [CrossRef]

73. El-Benna, J.; Hurtado-Nedelec, M.; Marzaioli, V.; Marie, J.C.; Gougerot-Pocidalo, M.A.; Dang, P.M. Priming of the neutrophil respiratory burst: Role in host defense and inflammation. Immunol. Rev. 2016, 273, 180-193. [CrossRef]

74. Schroder, K. NADPH oxidase-derived reactive oxygen species: Dosis facit venenum. Exp. Physiol. 2019, 104, 447-452. [CrossRef] [PubMed]

75. Singel, K.L.; Segal, B.H. NOX2-dependent regulation of inflammation. Clin. Sci. 2016, 130, 479-490. [CrossRef] [PubMed]

76. Light, D.R.; Walsh, C.; O'Callaghan, A.M.; Goetzl, E.J.; Tauber, A.I. Characteristics of the cofactor requirements for the superoxidegenerating NADPH oxidase of human polymorphonuclear leukocytes. Biochemistry 1981, 20, 1468-1476. [CrossRef] [PubMed] 
77. Decoursey, T.E.; Ligeti, E. Regulation and termination of NADPH oxidase activity. Cell Mol. Life Sci. 2005, 62, $2173-2193$. [CrossRef]

78. Lugrin, J.; Rosenblatt-Velin, N.; Parapanov, R.; Liaudet, L. The role of oxidative stress during inflammatory processes. Biol. Chem. 2014, 395, 203-230. [CrossRef] [PubMed]

79. Hunter, P. The inflammation theory of disease. The growing realization that chronic inflammation is crucial in many diseases opens new avenues for treatment. EMBO Rep. 2012, 13, 968-970. [CrossRef]

80. Zindel, J.; Kubes, P. DAMPs, PAMPs, and LAMPs in Immunity and Sterile Inflammation. Annu. Rev. Pathol. 2020, 15, 493-518. [CrossRef]

81. Broz, P.; Dixit, V.M. Inflammasomes: Mechanism of assembly, regulation and signalling. Nat. Rev. Immunol. 2016, 16, 407-420. [CrossRef] [PubMed]

82. Abais, J.M.; Xia, M.; Zhang, Y.; Boini, K.M.; Li, P.L. Redox regulation of NLRP3 inflammasomes: ROS as trigger or effector? Antioxid. Redox Signal. 2015, 22, 1111-1129. [CrossRef]

83. Sanchez-Rodriguez, R.; Munari, F.; Angioni, R.; Venegas, F.; Agnellini, A.; Castro-Gil, M.P.; Castegna, A.; Luisetto, R.; Viola, A.; Canton, M. Targeting monoamine oxidase to dampen NLRP3 inflammasome activation in inflammation. Cell Mol. Immunol. 2020. [CrossRef]

84. Zhong, Z.; Zhai, Y.; Liang, S.; Mori, Y.; Han, R.; Sutterwala, F.S.; Qiao, L. TRPM2 links oxidative stress to NLRP3 inflammasome activation. Nat. Commun. 2013, 4, 1611. [CrossRef]

85. Gatliff, J.; East, D.A.; Singh, A.; Alvarez, M.S.; Frison, M.; Matic, I.; Ferraina, C.; Sampson, N.; Turkheimer, F.; Campanella, M. A role for TSPO in mitochondrial $\mathrm{Ca}^{2+}$ homeostasis and redox stress signaling. Cell Death Dis. 2017, 8, e2896. [CrossRef]

86. Horng, T. Calcium signaling and mitochondrial destabilization in the triggering of the NLRP3 inflammasome. Trends Immunol. 2014, 35, 253-261. [CrossRef]

87. Bergsbaken, T.; Fink, S.L.; Cookson, B.T. Pyroptosis: Host cell death and inflammation. Nat. Rev. Microbiol. 2009, 7, 99-109. [CrossRef]

88. Zheng, D.; Liwinski, T.; Elinav, E. Inflammasome activation and regulation: Toward a better understanding of complex mechanisms. Cell Discov. 2020, 6, 36. [CrossRef] [PubMed]

89. Orning, P.; Lien, E.; Fitzgerald, K.A. Gasdermins and their role in immunity and inflammation. J. Exp. Med. 2019, 216, 2453-2465. [CrossRef] [PubMed]

90. Broz, P.; Pelegrin, P.; Shao, F. The gasdermins, a protein family executing cell death and inflammation. Nat. Rev. Immunol. 2020, 20, 143-157. [CrossRef] [PubMed]

91. Swanson, K.V.; Deng, M.; Ting, J.P. The NLRP3 inflammasome: Molecular activation and regulation to therapeutics. Nat. Rev. Immunol. 2019, 19, 477-489. [CrossRef]

92. Dinarello, C.A.; Simon, A.; van der Meer, J.W. Treating inflammation by blocking interleukin-1 in a broad spectrum of diseases. Nat. Rev. Drug Discov. 2012, 11, 633-652. [CrossRef] [PubMed]

93. Schwaid, A.G.; Spencer, K.B. Strategies for Targeting the NLRP3 Inflammasome in the Clinical and Preclinical Space. J. Med. Chem. 2021, 64, 101-122. [CrossRef]

94. Mangan, M.S.J.; Olhava, E.J.; Roush, W.R.; Seidel, H.M.; Glick, G.D.; Latz, E. Targeting the NLRP3 inflammasome in inflammatory diseases. Nat. Rev. Drug Discov. 2018, 17, 588-606. [CrossRef]

95. Marin, I.A.; Kipnis, J. Central Nervous System: (Immunological) Ivory Tower or Not? Neuropsychopharmacology 2017, 42, 28-35. [CrossRef]

96. Galea, I.; Bechmann, I.; Perry, V.H. What is immune privilege (not)? Trends Immunol. 2007, 28, 12-18. [CrossRef]

97. Hartenstein, V.; Giangrande, A. Connecting the nervous and the immune systems in evolution. Commun. Biol. 2018, 1, 64. [CrossRef]

98. Bennett, M.L.; Bennett, F.C. The influence of environment and origin on brain resident macrophages and implications for therapy. Nat. Neurosci. 2020, 23, 157-166. [CrossRef] [PubMed]

99. Lannes, N.; Eppler, E.; Etemad, S.; Yotovski, P.; Filgueira, L. Microglia at center stage: A comprehensive review about the versatile and unique residential macrophages of the central nervous system. Oncotarget 2017, 8, 114393-114413. [CrossRef]

100. Kaushal, V.; Dye, R.; Pakavathkumar, P.; Foveau, B.; Flores, J.; Hyman, B.; Ghetti, B.; Koller, B.H.; LeBlanc, A.C. Neuronal NLRP1 inflammasome activation of Caspase-1 coordinately regulates inflammatory interleukin-1-beta production and axonal degeneration-associated Caspase-6 activation. Cell Death Differ. 2015, 22, 1676-1686. [CrossRef] [PubMed]

101. Freeman, L.; Guo, H.; David, C.N.; Brickey, W.J.; Jha, S.; Ting, J.P. NLR members NLRC4 and NLRP3 mediate sterile inflammasome activation in microglia and astrocytes. J. Exp. Med. 2017, 214, 1351-1370. [CrossRef]

102. Kawana, N.; Yamamoto, Y.; Ishida, T.; Saito, Y.; Konno, H.; Arima, K.; Satoh, J.-I. Reactive astrocytes and perivascular macrophages express NLRP3 inflammasome in active demyelinating lesions of multiple sclerosis and necrotic lesions of neuromyelitis optica and cerebral infarction. Clin. Exp. Neuroimmunol. 2013, 4, 296-304. [CrossRef]

103. McKenzie, B.A.; Mamik, M.K.; Saito, L.B.; Boghozian, R.; Monaco, M.C.; Major, E.O.; Lu, J.Q.; Branton, W.G.; Power, C. Caspase-1 inhibition prevents glial inflammasome activation and pyroptosis in models of multiple sclerosis. Proc. Natl. Acad. Sci. USA 2018, 115, E6065-E6074. [CrossRef]

104. Gong, Z.; Pan, J.; Shen, Q.; Li, M.; Peng, Y. Mitochondrial dysfunction induces NLRP3 inflammasome activation during cerebral ischemia/reperfusion injury. J. Neuroinflamm. 2018, 15, 242. [CrossRef] 
105. Welser-Alves, J.V.; Milner, R. Microglia are the major source of TNF-alpha and TGF-beta1 in postnatal glial cultures; regulation by cytokines, lipopolysaccharide, and vitronectin. Neurochem. Int. 2013, 63, 47-53. [CrossRef]

106. West, P.K.; Viengkhou, B.; Campbell, I.L.; Hofer, M.J. Microglia responses to interleukin-6 and type I interferons in neuroinflammatory disease. Glia 2019, 67, 1821-1841. [CrossRef]

107. Herzog, C.; Pons Garcia, L.; Keatinge, M.; Greenald, D.; Moritz, C.; Peri, F.; Herrgen, L. Rapid clearance of cellular debris by microglia limits secondary neuronal cell death after brain injury in vivo. Development 2019, 146. [CrossRef] [PubMed]

108. Claude, J.; Linnartz-Gerlach, B.; Kudin, A.P.; Kunz, W.S.; Neumann, H. Microglial CD33-related Siglec-E inhibits neurotoxicity by preventing the phagocytosis-associated oxidative burst. J. Neurosci. 2013, 33, 18270-18276. [CrossRef] [PubMed]

109. Simpson, D.S.A.; Oliver, P.L. ROS Generation in Microglia: Understanding Oxidative Stress and Inflammation in Neurodegenerative Disease. Antioxidants 2020, 9, 743. [CrossRef]

110. Elenkov, I.J.; Iezzoni, D.G.; Daly, A.; Harris, A.G.; Chrousos, G.P. Cytokine dysregulation, inflammation and well-being. Neuroimmunomodulation 2005, 12, 255-269. [CrossRef] [PubMed]

111. Chen, L.; Deng, H.; Cui, H.; Fang, J.; Zuo, Z.; Deng, J.; Li, Y.; Wang, X.; Zhao, L. Inflammatory responses and inflammationassociated diseases in organs. Oncotarget 2018, 9, 7204-7218. [CrossRef]

112. Varatharaj, A.; Galea, I. The blood-brain barrier in systemic inflammation. Brain Behav. Immun. 2017, 60, 1-12. [CrossRef]

113. Profaci, C.P.; Munji, R.N.; Pulido, R.S.; Daneman, R. The blood-brain barrier in health and disease: Important unanswered questions. J. Exp. Med. 2020, 217. [CrossRef] [PubMed]

114. Fogal, B.; Hewett, S.J. Interleukin-1beta: A bridge between inflammation and excitotoxicity? J. Neurochem. 2008, 106, 1-23. [CrossRef]

115. Floyd, R.A.; Hensley, K.; Jaffery, F.; Maidt, L.; Robinson, K.; Pye, Q.; Stewart, C. Increased oxidative stress brought on by pro-inflammatory cytokines in neurodegenerative processes and the protective role of nitrone-based free radical traps. Life Sci. 1999, 65, 1893-1899. [CrossRef]

116. Thornton, P.; Pinteaux, E.; Gibson, R.M.; Allan, S.M.; Rothwell, N.J. Interleukin-1-induced neurotoxicity is mediated by glia and requires caspase activation and free radical release. J. Neurochem. 2006, 98, 258-266. [CrossRef]

117. Campbell, I.L.; Abraham, C.R.; Masliah, E.; Kemper, P.; Inglis, J.D.; Oldstone, M.B.; Mucke, L. Neurologic disease induced in transgenic mice by cerebral overexpression of interleukin 6. Proc. Natl. Acad. Sci. USA 1993, 90, 10061-10065. [CrossRef] [PubMed]

118. Fattori, E.; Lazzaro, D.; Musiani, P.; Modesti, A.; Alonzi, T.; Ciliberto, G. IL-6 expression in neurons of transgenic mice causes reactive astrocytosis and increase in ramified microglial cells but no neuronal damage. Eur. J. Neurosci. 1995, 7, $2441-2449$. [CrossRef] [PubMed]

119. Eugster, H.P.; Frei, K.; Kopf, M.; Lassmann, H.; Fontana, A. IL-6-deficient mice resist myelin oligodendrocyte glycoprotein-induced autoimmune encephalomyelitis. Eur. J. Immunol. 1998, 28, 2178-2187. [CrossRef]

120. Beattie, E.C.; Stellwagen, D.; Morishita, W.; Bresnahan, J.C.; Ha, B.K.; Von Zastrow, M.; Beattie, M.S.; Malenka, R.C. Control of synaptic strength by glial TNFalpha. Science 2002, 295, 2282-2285. [CrossRef]

121. Zou, J.Y.; Crews, F.T. TNF alpha potentiates glutamate neurotoxicity by inhibiting glutamate uptake in organotypic brain slice cultures: Neuroprotection by NF kappa B inhibition. Brain Res. 2005, 1034, 11-24. [CrossRef]

122. Schwarzlander, M.; Dick, T.P.; Meyer, A.J.; Morgan, B. Dissecting Redox Biology Using Fluorescent Protein Sensors. Antioxid. Redox Signal. 2016, 24, 680-712. [CrossRef] [PubMed]

123. Jiang, X.; Wang, L.; Carroll, S.L.; Chen, J.; Wang, M.C.; Wang, J. Challenges and Opportunities for Small-Molecule Fluorescent Probes in Redox Biology Applications. Antioxid. Redox Signal. 2018, 29, 518-540. [CrossRef] [PubMed]

124. Ikawa, M.; Okazawa, H.; Nakamoto, Y.; Yoneda, M. PET Imaging for Oxidative Stress in Neurodegenerative Disorders Associated with Mitochondrial Dysfunction. Antioxidants 2020, 9, 861. [CrossRef]

125. Sugiura, K.; Mihara, S.; Fu, N.; Hisabori, T. Real-time monitoring of the in vivo redox state transition using the ratiometric redox state sensor protein FROG/B. Proc. Natl. Acad. Sci. USA 2020, 117, 16019-16026. [CrossRef]

126. Zhao, Y.; Zhang, Z.; Zou, Y.; Yang, Y. Visualization of Nicotine Adenine Dinucleotide Redox Homeostasis with Genetically Encoded Fluorescent Sensors. Antioxid. Redox Signal. 2018, 28, 213-229. [CrossRef]

127. Hatori, Y.; Kubo, T.; Sato, Y.; Inouye, S.; Akagi, R.; Seyama, T. Visualization of the Redox Status of Cytosolic Glutathione Using the Organelle- and Cytoskeleton-Targeted Redox Sensors. Antioxidants 2020, 9, 129. [CrossRef]

128. Kostyuk, A.I.; Panova, A.S.; Kokova, A.D.; Kotova, D.A.; Maltsev, D.I.; Podgorny, O.V.; Belousov, V.V.; Bilan, D.S. In Vivo Imaging with Genetically Encoded Redox Biosensors. Int. J. Mol. Sci. 2020, 21, 8164. [CrossRef]

129. Formella, I.; Svahn, A.J.; Radford, R.A.W.; Don, E.K.; Cole, N.J.; Hogan, A.; Lee, A.; Chung, R.S.; Morsch, M. Real-time visualization of oxidative stress-mediated neurodegeneration of individual spinal motor neurons in vivo. Redox Biol. 2018, 19, 226-234. [CrossRef] [PubMed]

130. Leslie, K.G.; Kolanowski, J.L.; Trinh, N.; Carrara, S.; Anscomb, M.D.; Yang, K.; Hogan, C.F.; Jolliffe, K.A.; New, E.J. NicotinamideAppended Fluorophores as Fluorescent Redox Sensors. Aust. J. Chem. 2020, 73, 895-902. [CrossRef]

131. Ni, Y.; Liu, H.; Dai, D.; Mu, X.; Xu, J.; Shao, S. Chromogenic, Fluorescent, and Redox Sensors for Multichannel Imaging and Detection of Hydrogen Peroxide in Living Cell Systems. Anal. Chem. 2018, 90, 10152-10158. [CrossRef] 
132. Balke, J.; Volz, P.; Neumann, F.; Brodwolf, R.; Wolf, A.; Pischon, H.; Radbruch, M.; Mundhenk, L.; Gruber, A.D.; Ma, N.; et al. Visualizing Oxidative Cellular Stress Induced by Nanoparticles in the Subcytotoxic Range Using Fluorescence Lifetime Imaging. Small 2018, 14, e1800310. [CrossRef] [PubMed]

133. Baltsavias, S.; Van Treuren, W.; Weber, M.J.; Charthad, J.; Baker, S.; Sonnenburg, J.L.; Arbabian, A. In Vivo Wireless Sensors for Gut Microbiome Redox Monitoring. IEEE Trans. Biomed. Eng. 2020, 67, 1821-1830. [CrossRef] [PubMed]

134. Massoud, T.F.; Gambhir, S.S. Molecular imaging in living subjects: Seeing fundamental biological processes in a new light. Genes Dev. 2003, 17, 545-580. [CrossRef]

135. Willmann, J.K.; van Bruggen, N.; Dinkelborg, L.M.; Gambhir, S.S. Molecular imaging in drug development. Nat. Rev. Drug Discov. 2008, 7, 591-607. [CrossRef] [PubMed]

136. Piel, M.; Vernaleken, I.; Rosch, F. Positron emission tomography in CNS drug discovery and drug monitoring. J. Med. Chem. 2014, 57, 9232-9258. [CrossRef] [PubMed]

137. Chu, W.; Chepetan, A.; Zhou, D.; Shoghi, K.I.; Xu, J.; Dugan, L.L.; Gropler, R.J.; Mintun, M.A.; Mach, R.H. Development of a PET radiotracer for non-invasive imaging of the reactive oxygen species, superoxide, in vivo. Org. Biomol. Chem. 2014, 12, $4421-4431$. [CrossRef] [PubMed]

138. Hou, C.; Hsieh, C.J.; Li, S.; Lee, H.; Graham, T.J.; Xu, K.; Weng, C.C.; Doot, R.K.; Chu, W.; Chakraborty, S.K.; et al. Development of a Positron Emission Tomography Radiotracer for Imaging Elevated Levels of Superoxide in Neuroinflammation. ACS Chem. Neurosci. 2018, 9, 578-586. [CrossRef] [PubMed]

139. Wilson, A.A.; Sadovski, O.; Nobrega, J.N.; Raymond, R.J.; Bambico, F.R.; Nashed, M.G.; Garcia, A.; Bloomfield, P.M.; Houle, S.; Mizrahi, R.; et al. Evaluation of a novel radiotracer for positron emission tomography imaging of reactive oxygen species in the central nervous system. Nucl. Med. Biol. 2017, 53, 14-20. [CrossRef]

140. Egami, H.; Nakagawa, S.; Katsura, Y.; Kanazawa, M.; Nishiyama, S.; Sakai, T.; Arano, Y.; Tsukada, H.; Inoue, O.; Todoroki, K.; et al. (18)F-Labeled dihydromethidine: Positron emission tomography radiotracer for imaging of reactive oxygen species in intact brain. Org. Biomol. Chem. 2020, 18, 2387-2391. [CrossRef]

141. Carroll, V.N.; Truillet, C.; Shen, B.; Flavell, R.R.; Shao, X.; Evans, M.J.; VanBrocklin, H.F.; Scott, P.J.; Chin, F.T.; Wilson, D.M. $[(11) C]$ Ascorbic and $[(11) C]$ dehydroascorbic acid, an endogenous redox pair for sensing reactive oxygen species using positron emission tomography. Chem. Commun. 2016, 52, 4888-4890. [CrossRef] [PubMed]

142. Carroll, V.; Michel, B.W.; Blecha, J.; Van Brocklin, H.; Keshari, K.; Wilson, D.; Chang, C.J. A boronate-caged [(1)(8)F]FLT probe for hydrogen peroxide detection using positron emission tomography. J. Am. Chem. Soc. 2014, 136, 14742-14745. [CrossRef]

143. Fujibayashi, Y.; Taniuchi, H.; Yonekura, Y.; Ohtani, H.; Konishi, J.; Yokoyama, A. Copper-62-ATSM: A new hypoxia imaging agent with high membrane permeability and low redox potential. J. Nucl. Med. 1997, 38, 1155-1160. [PubMed]

144. Gangemi, V.; Mignogna, C.; Guzzi, G.; Lavano, A.; Bongarzone, S.; Cascini, G.L.; Sabatini, U. Impact of [(64)Cu][Cu(ATSM)] $\mathrm{PET} / \mathrm{CT}$ in the evaluation of hypoxia in a patient with Glioblastoma: A case report. BMC Cancer 2019, 19, 1197. [CrossRef] [PubMed]

145. Lewerenz, J.; Hewett, S.J.; Huang, Y.; Lambros, M.; Gout, P.W.; Kalivas, P.W.; Massie, A.; Smolders, I.; Methner, A.; Pergande, M.; et al. The cystine/glutamate antiporter system $\mathrm{x}(\mathrm{c})(-)$ in health and disease: From molecular mechanisms to novel therapeutic opportunities. Antioxid. Redox Signal. 2013, 18, 522-555. [CrossRef]

146. Koglin, N.; Mueller, A.; Berndt, M.; Schmitt-Willich, H.; Toschi, L.; Stephens, A.W.; Gekeler, V.; Friebe, M.; Dinkelborg, L.M. Specific PET imaging of $\mathrm{xC}$ - transporter activity using a (1)(8)F-labeled glutamate derivative reveals a dominant pathway in tumor metabolism. Clin. Cancer Res. 2011, 17, 6000-6011. [CrossRef]

147. Park, S.Y.; Na, S.J.; Kumar, M.; Mosci, C.; Wardak, M.; Koglin, N.; Bullich, S.; Mueller, A.; Berndt, M.; Stephens, A.W.; et al. Clinical Evaluation of (4S)-4-(3-[(18)F]Fluoropropyl)-L-glutamate ((18)F-FSPG) for PET/CT Imaging in Patients with Newly Diagnosed and Recurrent Prostate Cancer. Clin. Cancer Res. 2020, 26, 5380-5387. [CrossRef]

148. Chae, S.Y.; Choi, C.M.; Shim, T.S.; Park, Y.; Park, C.S.; Lee, H.S.; Lee, S.J.; Oh, S.J.; Kim, S.Y.; Baek, S.; et al. Exploratory Clinical Investigation of (4S)-4-(3-18F-Fluoropropyl)-L-Glutamate PET of Inflammatory and Infectious Lesions. J. Nucl. Med. 2016, 57, 67-69. [CrossRef]

149. Kreisl, W.C.; Kim, M.-J.; Coughlin, J.M.; Henter, I.D.; Owen, D.R.; Innis, R.B. PET imaging of neuroinflammation in neurological disorders. Lancet Neurol. 2020, 19, 940-950. [CrossRef]

150. Jain, P.; Chaney, A.M.; Carlson, M.L.; Jackson, I.M.; Rao, A.; James, M.L. Neuroinflammation PET Imaging: Current Opinion and Future Directions. J. Nucl. Med. 2020, 61, 1107-1112. [CrossRef]

151. Betlazar, C.; Middleton, R.J.; Banati, R.; Liu, G.-J. The Translocator Protein (TSPO) in Mitochondrial Bioenergetics and Immune Processes. Cells 2020, 9, 512. [CrossRef]

152. Zorov, D.B.; Juhaszova, M.; Sollott, S.J. Mitochondrial Reactive Oxygen Species (ROS) and ROS-Induced ROS Release. Physiol. Rev. 2014, 94, 909-950. [CrossRef]

153. Guilarte, T.R. TSPO in diverse CNS pathologies and psychiatric disease: A critical review and a way forward. Pharmacol. Ther. 2019, 194, 44-58. [CrossRef] [PubMed]

154. Ilkan, Z.; Akar, F.G. The Mitochondrial Translocator Protein and the Emerging Link Between Oxidative Stress and Arrhythmias in the Diabetic Heart. Front. Physiol. 2018, 9, 1518. [CrossRef] [PubMed] 
155. Beckers, L.; Ory, D.; Geric, I.; Declercq, L.; Koole, M.; Kassiou, M.; Bormans, G.; Baes, M. Increased Expression of Translocator Protein (TSPO) Marks Pro-inflammatory Microglia but Does Not Predict Neurodegeneration. Mol. Imaging Biol. 2018, $20,94-102$. [CrossRef] [PubMed]

156. Venneti, S.; Lopresti, B.J.; Wiley, C.A. The peripheral benzodiazepine receptor (Translocator protein 18kDa) in microglia: From pathology to imaging. Prog. Neurobiol. 2006, 80, 308-322. [CrossRef]

157. Marangos, P.J.; Patel, J.; Boulenger, J.P.; Clark-Rosenberg, R. Characterization of peripheral-type benzodiazepine binding sites in brain using [3H]Ro 5-4864. Mol. Pharmacol. 1982, 22, 26-32.

158. Papadopoulos, V.; Baraldi, M.; Guilarte, T.R.; Knudsen, T.B.; Lacapere, J.J.; Lindemann, P.; Norenberg, M.D.; Nutt, D.; Weizman, A.; Zhang, M.R.; et al. Translocator protein (18kDa): New nomenclature for the peripheral-type benzodiazepine receptor based on its structure and molecular function. Trends Pharmacol. Sci. 2006, 27, 402-409. [CrossRef]

159. Dubois, A.; Benavides, J.; Peny, B.; Duverger, D.; Fage, D.; Gotti, B.; MacKenzie, E.T.; Scatton, B. Imaging of primary and remote ischaemic and excitotoxic brain lesions. An autoradiographic study of peripheral type benzodiazepine binding sites in the rat and cat. Brain Res. 1988, 445, 77-90. [CrossRef]

160. Banati, R.B.; Newcombe, J.; Gunn, R.N.; Cagnin, A.; Turkheimer, F.; Heppner, F.; Price, G.; Wegner, F.; Giovannoni, G.; Miller, D.H.; et al. The peripheral benzodiazepine binding site in the brain in multiple sclerosis: Quantitative in vivo imaging of microglia as a measure of disease activity. Brain 2000, 123 Pt 11, 2321-2337. [CrossRef]

161. Jucaite, A.; Cselenyi, Z.; Arvidsson, A.; Ahlberg, G.; Julin, P.; Varnas, K.; Stenkrona, P.; Andersson, J.; Halldin, C.; Farde, L. Kinetic analysis and test-retest variability of the radioligand [11C](R)-PK11195 binding to TSPO in the human brain-A PET study in control subjects. EJNMMI Res. 2012, 2, 15. [CrossRef]

162. Chauveau, F.; Van Camp, N.; Dolle, F.; Kuhnast, B.; Hinnen, F.; Damont, A.; Boutin, H.; James, M.; Kassiou, M.; Tavitian, B. Comparative evaluation of the translocator protein radioligands 11C-DPA-713, 18F-DPA-714, and 11C-PK11195 in a rat model of acute neuroinflammation. J. Nucl. Med. 2009, 50, 468-476. [CrossRef] [PubMed]

163. Mizrahi, R.; Rusjan, P.M.; Kennedy, J.; Pollock, B.; Mulsant, B.; Suridjan, I.; De Luca, V.; Wilson, A.A.; Houle, S. Translocator protein $(18 \mathrm{kDa})$ polymorphism (rs6971) explains in-vivo brain binding affinity of the PET radioligand [(18)F]-FEPPA. J. Cereb. Blood Flow Metab. 2012, 32, 968-972. [CrossRef] [PubMed]

164. Zanotti-Fregonara, P.; Pascual, B.; Veronese, M.; Yu, M.; Beers, D.; Appel, S.H.; Masdeu, J.C. Head-to-head comparison of (11)C-PBR28 and (11)C-ER176 for quantification of the translocator protein in the human brain. Eur. J. Nucl. Med. Mol. Imaging 2019, 46, 1822-1829. [CrossRef] [PubMed]

165. Ottoy, J.; De Picker, L.; Verhaeghe, J.; Deleye, S.; Wyffels, L.; Kosten, L.; Sabbe, B.; Coppens, V.; Timmers, M.; van Nueten, L.; et al. (18)F-PBR111 PET Imaging in Healthy Controls and Schizophrenia: Test-Retest Reproducibility and Quantification of Neuroinflammation. J. Nucl. Med. 2018, 59, 1267-1274. [CrossRef]

166. Tondo, G.; Iaccarino, L.; Cerami, C.; Vanoli, G.E.; Presotto, L.; Masiello, V.; Coliva, A.; Salvi, F.; Bartolomei, I.; Mosca, L.; et al. (11) C-PK11195 PET-based molecular study of microglia activation in SOD1 amyotrophic lateral sclerosis. Ann. Clin. Transl. Neurol. 2020. [CrossRef]

167. Bradburn, S.; Murgatroyd, C.; Ray, N. Neuroinflammation in mild cognitive impairment and Alzheimer's disease: A meta-analysis. Ageing Res. Rev. 2019, 50, 1-8. [CrossRef] [PubMed]

168. Cerami, C.; Iaccarino, L.; Perani, D. Molecular Imaging of Neuroinflammation in Neurodegenerative Dementias: The Role of In Vivo PET Imaging. Int. J. Mol. Sci. 2017, 18, 993. [CrossRef]

169. Sucksdorff, M.; Tuisku, J.; Matilainen, M.; Vuorimaa, A.; Smith, S.; Keitila, J.; Rokka, J.; Parkkola, R.; Nylund, M.; Rinne, J.; et al. Natalizumab treatment reduces microglial activation in the white matter of the MS brain. Neurol. Neuroimmunol. Neuroinflamm. 2019, 6, e574. [CrossRef]

170. Herranz, E.; Gianni, C.; Louapre, C.; Treaba, C.A.; Govindarajan, S.T.; Ouellette, R.; Loggia, M.L.; Sloane, J.A.; Madigan, N.; Izquierdo-Garcia, D.; et al. Neuroinflammatory component of gray matter pathology in multiple sclerosis. Ann. Neurol. 2016, 80, 776-790. [CrossRef]

171. Narayanaswami, V.; Dahl, K.; Bernard-Gauthier, V.; Josephson, L.; Cumming, P.; Vasdev, N. Emerging PET Radiotracers and Targets for Imaging of Neuroinflammation in Neurodegenerative Diseases: Outlook Beyond TSPO. Mol. Imaging 2018, 17, 1536012118792317. [CrossRef]

172. Edmondson, D.E.; Binda, C.; Wang, J.; Upadhyay, A.K.; Mattevi, A. Molecular and mechanistic properties of the membrane-bound mitochondrial monoamine oxidases. Biochemistry 2009, 48, 4220-4230. [CrossRef]

173. Cohen, G.; Kesler, N. Monoamine oxidase and mitochondrial respiration. J. Neurochem. 1999, 73, 2310-2315. [CrossRef] [PubMed]

174. Ekblom, J.; Jossan, S.S.; Oreland, L.; Walum, E.; Aquilonius, S.M. Reactive gliosis and monoamine oxidase B. J. Neural. Transm. Suppl. 1994, 41, 253-258. [CrossRef]

175. Saura, J.; Kettler, R.; Da Prada, M.; Richards, J.G. Quantitative enzyme radioautography with 3H-Ro 41-1049 and 3H-Ro 19-6327 in vitro: Localization and abundance of MAO-A and MAO-B in rat CNS, peripheral organs, and human brain. J. Neurosci. 1992, 12, 1977-1999. [CrossRef] [PubMed]

176. Fowler, J.S.; MacGregor, R.R.; Wolf, A.P.; Arnett, C.D.; Dewey, S.L.; Schlyer, D.; Christman, D.; Logan, J.; Smith, M.; Sachs, H.; et al. Mapping human brain monoamine oxidase A and B with 11C-labeled suicide inactivators and PET. Science 1987, 235, 481-485. [CrossRef] [PubMed] 
177. Narayanaswami, V.; Drake, L.R.; Brooks, A.F.; Meyer, J.H.; Houle, S.; Kilbourn, M.R.; Scott, P.J.H.; Vasdev, N. Classics in Neuroimaging: Development of PET Tracers for Imaging Monoamine Oxidases. ACS Chem. Neurosci. 2019, 10, $1867-1871$. [CrossRef]

178. Arakawa, R.; Stenkrona, P.; Takano, A.; Nag, S.; Maior, R.S.; Halldin, C. Test-retest reproducibility of [(11)C]-L-deprenyl-D2 binding to MAO-B in the human brain. EJNMMI Res. 2017, 7, 54. [CrossRef]

179. Hirvonen, J.; Kailajarvi, M.; Haltia, T.; Koskimies, S.; Nagren, K.; Virsu, P.; Oikonen, V.; Sipila, H.; Ruokoniemi, P.; Virtanen, K.; et al. Assessment of MAO-B occupancy in the brain with PET and [11C]-L-deprenyl-D2: A dose-finding study with a novel MAO-B inhibitor, EVT 301. Clin. Pharmacol. Ther. 2009, 85, 506-512. [CrossRef]

180. Tong, J.; Meyer, J.H.; Furukawa, Y.; Boileau, I.; Chang, L.J.; Wilson, A.A.; Houle, S.; Kish, S.J. Distribution of monoamine oxidase proteins in human brain: Implications for brain imaging studies. J. Cereb. Blood Flow Metab. 2013, 33, 863-871. [CrossRef]

181. Cumming, P.; Yokoi, F.; Chen, A.; Deep, P.; Dagher, A.; Reutens, D.; Kapczinski, F.; Wong, D.F.; Gjedde, A. Pharmacokinetics of radiotracers in human plasma during positron emission tomography. Synapse 1999, 34, 124-134. [CrossRef]

182. Fowler, J.S.; Wang, G.J.; Logan, J.; Xie, S.; Volkow, N.D.; MacGregor, R.R.; Schlyer, D.J.; Pappas, N.; Alexoff, D.L.; Patlak, C.; et al. Selective reduction of radiotracer trapping by deuterium substitution: Comparison of carbon-11-L-deprenyl and carbon-11-deprenyl-D2 for MAO B mapping. J. Nucl. Med. 1995, 36, 1255-1262.

183. Bramoullé, Y.; Puech, F.; Saba, W.; Valette, H.; Bottlaender, M.; George, P.; Dollé, F. Radiosynthesis of (S)-5-methoxymethyl3-[6-(4,4,4-trifluorobutoxy)benzo[d]isoxazol-3-yl] oxazolidin-2-[11C]one ([11C]SL25.1188), a novel radioligand for imaging monoamine oxidase-B with PET. J. Label. Compd. Radiopharm. 2008, 51, 153-158. [CrossRef]

184. Saba, W.; Valette, H.; Peyronneau, M.A.; Bramoulle, Y.; Coulon, C.; Curet, O.; George, P.; Dolle, F.; Bottlaender, M. [(11)C]SL25.1188, a new reversible radioligand to study the monoamine oxidase type B with PET: Preclinical characterisation in nonhuman primate. Synapse 2010, 64, 61-69. [CrossRef] [PubMed]

185. Rusjan, P.M.; Wilson, A.A.; Miler, L.; Fan, I.; Mizrahi, R.; Houle, S.; Vasdev, N.; Meyer, J.H. Kinetic modeling of the monoamine oxidase B radioligand [(1)(1)C]SL25.1188 in human brain with high-resolution positron emission tomography. J. Cereb. Blood Flow Metab. 2014, 34, 883-889. [CrossRef]

186. Moriguchi, S.; Wilson, A.A.; Miler, L.; Rusjan, P.M.; Vasdev, N.; Kish, S.J.; Rajkowska, G.; Wang, J.; Bagby, M.; Mizrahi, R.; et al. Monoamine Oxidase B Total Distribution Volume in the Prefrontal Cortex of Major Depressive Disorder: An [11C]SL25.1188 Positron Emission Tomography Study. JAMA Psychiatry 2019, 76, 634-641. [CrossRef]

187. Evans, N.R.; Tarkin, J.M.; Buscombe, J.R.; Markus, H.S.; Rudd, J.H.F.; Warburton, E.A. PET imaging of the neurovascular interface in cerebrovascular disease. Nat. Rev. Neurol. 2017, 13, 676-688. [CrossRef] [PubMed]

188. Boutin, H.; Pinborg, L.H. TSPO imaging in stroke: From animal models to human subjects. Clin. Transl. Imaging 2015, 3, 423-435. [CrossRef]

189. Zinnhardt, B.; Wiesmann, M.; Honold, L.; Barca, C.; Schafers, M.; Kiliaan, A.J.; Jacobs, A.H. In vivo imaging biomarkers of neuroinflammation in the development and assessment of stroke therapies-towards clinical translation. Theranostics 2018, 8, 2603-2620. [CrossRef]

190. La Joie, R.; Visani, A.V.; Baker, S.L.; Brown, J.A.; Bourakova, V.; Cha, J.; Chaudhary, K.; Edwards, L.; Iaccarino, L.; Janabi, M.; et al. Prospective longitudinal atrophy in Alzheimer's disease correlates with the intensity and topography of baseline tau-PET. Sci. Transl. Med. 2020, 12. [CrossRef]

191. Lagarde, J.; Sarazin, M.; Bottlaender, M. In vivo PET imaging of neuroinflammation in Alzheimer's disease. J. Neural Transm. 2018, 125, 847-867. [CrossRef] [PubMed]

192. Edison, P.; Donat, C.K.; Sastre, M. In vivo Imaging of Glial Activation in Alzheimer's Disease. Front. Neurol. 2018,9 , 625. [CrossRef] [PubMed]

193. Ismail, R.; Parbo, P.; Madsen, L.S.; Hansen, A.K.; Hansen, K.V.; Schaldemose, J.L.; Kjeldsen, P.L.; Stokholm, M.G.; Gottrup, H.; Eskildsen, S.F.; et al. The relationships between neuroinflammation, beta-amyloid and tau deposition in Alzheimer's disease: A longitudinal PET study. J. Neuroinflam. 2020, 17, 151. [CrossRef]

194. Femminella, G.D.; Dani, M.; Wood, M.; Fan, Z.; Calsolaro, V.; Atkinson, R.; Edginton, T.; Hinz, R.; Brooks, D.J.; Edison, P. Microglial activation in early Alzheimer trajectory is associated with higher gray matter volume. Neurology 2019, 92, e1331-e1343. [CrossRef] [PubMed]

195. Rodriguez-Vieitez, E.; Saint-Aubert, L.; Carter, S.F.; Almkvist, O.; Farid, K.; Scholl, M.; Chiotis, K.; Thordardottir, S.; Graff, C.; Wall, A.; et al. Diverging longitudinal changes in astrocytosis and amyloid PET in autosomal dominant Alzheimer's disease. Brain 2016, 139, 922-936. [CrossRef] 